\title{
Blockade of CCR4 Diminishes Hypersensitivity and Enhances Opioid Analgesia - Evidence from a Mouse Model of Diabetic Neuropathy
}

\author{
Joanna Bogacka, ${ }^{\mathrm{a}}$ Katarzyna Ciapała, ${ }^{\mathrm{a}}$ Katarzyna Pawlik, ${ }^{\mathrm{a}}$ Jan Dobrogowski, ${ }^{\mathrm{b}}$ Anna Przeklasa-Muszynska ${ }^{\mathrm{b}}$ and \\ Joanna Mika ${ }^{\text {a* }}$ \\ ${ }^{a}$ Maj Institute of Pharmacology, Polish Academy of Sciences, Department of Pain Pharmacology, 12 Smetna Street, 31 -343 Krakow, Poland \\ ${ }^{\mathrm{b}}$ Department of Pain Research and Treatment, Chair of Anesthesiology and Intensive Therapy, Jagiellonian University Medical College, \\ Krakow, Poland
}

\begin{abstract}
Chemokine signaling has been implicated in the pathogenesis of diabetic neuropathy; however, the role of chemokine CC motif receptor 4 (CCR4) remains unknown. The goal was to examine the function of CCR4 in hypersensitivity development and opioid effectiveness in diabetic neuropathy. Streptozotocin (STZ; $200 \mathrm{mg} / \mathrm{kg}$, intraperitoneally administered)-induced mouse model of diabetic neuropathy were used. An analysis of the mRNA/protein expression of CCR4 and its ligands was performed by qRT-PCR, microarray and/or Western blot methods. C021 (CCR4 antagonist), morphine and buprenorphine were injected intrathecally or intraperitoneally, and pain-related behavior was evaluated by the von Frey, cold plate and rotarod tests. We observed that on day 7 after STZ administration, the blood glucose level was increased, and as a consequence, hypersensitivity to tactile and thermal stimuli developed. In addition, we observed an increase in the mRNA level of CCL2 but not CCL17/CCL22. The microarray technique showed that the CCL2 protein level was also upregulated. In naive mice, the pronociceptive effect of intrathecally injected CCL2 was blocked by C021, suggesting that this chemokine acts through CCR4. Importantly, our results provide the first evidence that in a mouse model of diabetic neuropathy, single intrathecal and intraperitoneal injections of C021 diminished neuropathic pain-related behavior in a dose-dependent manner and improved motor functions. Moreover, both single intrathecal and intraperitoneal injections of $\mathrm{C} 021$ enhanced morphine and buprenorphine effectiveness. These results reveal that pharmacological modulation of CCR4 may be a good potential therapeutic target for the treatment of diabetic neuropathy and may enhance the effectiveness of opioids. (C) 2020 The Author(s). Published by Elsevier Ltd on behalf of IBRO. This is an open access article under the CC BY license (http://creativecommons.org/licenses/by/4.0/).
\end{abstract}

Key words: C021 (CCR4 antagonist), morphine, buprenorphine, CCL17, CCL22, CCL2.

\section{INTRODUCTION}

Diabetes mellitus is an epidemic of the 21st century, and a recent report from the World Health Organization has shown that since 1980, the number of adults living with diabetes has nearly quadrupled to 422 million people (WHO, 2017). One of the most common complications is nerve impairment, which causes the development of neuropathic pain (Feldman et al., 2017). The molecular mechanisms involved in diabetic neuropathy are very complex (Zychowska et al., 2013b; Feldman et al., 2017); however, according to the latest research, cytokine

\footnotetext{
*Corresponding author. Address: Maj Institute of Pharmacology, Polish Academy of Sciences, Department of Pain Pharmacology, 12 Smetna Str., 31-343 Krakow, Poland. Tel: +48-12-6623240; fax: +48-12-6374500.

E-mail address: joamika@if-pan.krakow.pl (J. Mika).

Abbreviations: BCA, bicinchoninic acid; STZ, streptozotocin; TBST, Tween-20.
}

participation in this phenomenon is extremely important (Zychowska et al., 2013b, 2015; Ji et al., 2014; PopBusui et al., 2016; Rojewska et al., 2018). Recently, some chemokines from the large cytokine family have been recognized as important factors that contribute to diabetic neuropathy. It has already been suggested that chemokines belonging to three different subfamilies - XC: XCL1 (Zychowska et al., 2016), CC: CCL2 and CCL5 (Panee, 2012; Chou et al., 2016) and CXC: CXCL1, CXCL5, CXCL9, and CXCL12 (Zychowska et al., 2015) - play an important role in the development of diabetic neuropathic pain. Additionally, among the CC subfamily, CCL17 and CCL22 are also known to have pronociceptive properties (Bogacka et al. 2020); however, their spinal expression in nociception during diabetes has not been studied thus far. The main target of CCL17 and CCL22 is chemokine CC motif receptor 4 (CCR4) (Yoshie and Matsushima, 2015; Scheu et al., 2017); however, according to the literature, this receptor probably has an additional ligand with well-known pronociceptive proper- 
ties - CCL2 (Graves et al., 1999; McMillin et al., 2014). Therefore, the role of CCR4 in nociceptive transmission needs to be studied, especially since current references suggest chemokine receptors as promising targets for neuropathic pain management. For example, some studies, including ours, have indicated that blockade of CCchemokine receptors, CCR1 (Pawlik et al., 2020), CCR2 (Kwiatkowski et al., 2017) and CCR5 (Matsushita et al., 2014; Kwiatkowski et al., 2016; Piotrowska et al., 2016a), attenuates the neuropathic pain symptoms evoked by chronic constriction injury of the sciatic nerve in rats. Moreover, in this model, CCR1, CCR2 and CCR5 antagonists also enhance morphine effectiveness (Kwiatkowski et al., 2016, 2017; Pawlik et al., 2020). However, to date, few pharmacological studies on the use of chemokine antagonists have been performed in diabetic neuropathy. In streptozotocin-induced diabetic neuropathy, antagonists of CCR1 (Rojewska et al., 2018) and CCR2 (Aye-Mon et al., 2018) diminish pain-related behavior, in contrast to antagonists of CCR5 (Rojewska et al., 2018).

Therefore, since diabetic neuropathy is a neuroinflammatory disorder, in our opinion, investigations should focus on the still undefined role of the chemokine system. We hypothesized that CCR4 is important for nociceptive transmission in diabetic neuropathy and is as a consequence an interesting pharmacological target for pain relief. Therefore, the aim was to investigate changes in the spinal expression of CCR4 and its ligands (CCL17, CCL22, and CCL2) in a streptozotocin-induced mouse model of diabetic neuropathic pain. Moreover, another aim was to investigate whether C021, a CCR4 antagonist, is able to block the pronociceptive properties of CCL2. The next goal was to determine the dose-dependent effect of single intrathecal and intraperitoneal injections of $\mathrm{C} 021$ on tactile and thermal hypersensitivity and motor coordination in streptozotocin-treated mice. Furthermore, this study also aimed to evaluate how single intrathecal and intraperitoneal injections of $\mathrm{C} 021$ influence the analgesic effects of morphine and buprenorphine in this model of diabetic neuropathic pain.

\section{EXPERIMENTAL PROCEDURES}

\section{Animals}

All the experiments were performed on male Albino-Swiss mice purchased from Charles River (Germany). The animals (20-22 g) were housed in cages with sawdust under a light/dark cycle of 12/12 h. Water and food were available ad libitum. The experiments were carried out according to the NIH Guide for the Care and Use of Laboratory Animals and IASP recommendations (Zimmermann, 1983). All the procedures were approved by the II Local Ethics Committee on Animal Testing at the Maj Institute of Pharmacology, Polish Academy of Sciences (Krakow, Poland, LKE 75/2017, 1277/2015). Care was taken to minimize animal suffering and reduce the number of animals used in the experiments (3R policy).

\section{Mouse model of diabetic neuropathic pain}

Streptozotocin (STZ) is often used in experimental studies (Kamei et al., 1991; Dogrul et al., 2011; Ohsawa et al., 2011; Murakami et al., 2013) to induce diabetic neuropathy by the specific necrosis of pancreatic beta cells (Lenzen, 2008; Bishnoi et al., 2011). In our experiments, a single intraperitoneal (i.p.) injection of STZ (200 mg/ kg; Tocris, Bristol, United Kingdom), dissolved in water, was used to generate a model of type 1 diabetes (Lenzen, 2008; Murakami et al., 2013; Zychowska et al., 2015). As a control group, we used naive mice, which were injected with water. Blood was collected from the tail veins of the mice, and the glucose concentration was measured with an Accu-Chek Active glucometer (Warsaw, Poland). The mice were considered diabetic when the serum glucose levels were higher than $300 \mathrm{mg} / \mathrm{dl}$ at day 7 after STZ injection.

\section{Pharmacological study}

C021 dihydrochloride (C021, Tocris, Bristol, United Kingdom); RS504393 (Tocris, Warsaw, Poland), morphine hydrochloride (M; TEVA, Kutno, Poland); buprenorphine (B; Polfa S.A., Warsaw, Poland) and recombinant mouse CCL2 protein (R\&D Systems, Minneapolis, USA) were dissolved in V: water or DMSO (only for RS504393) for injection. The control groups were injected with water or DMSO at the same time points. Substances were administered intrathecally (i.t.) or intraperitoneally (i.p.). The i.t. injection was performed using a Hamilton syringe with a thin needle, in accordance with Hylden and Wilcox (Hylden and Wilcox, 1980) with later modifications (Fairbanks, 2003). The substances were injected into the lumbar region of the spinal cord (between the L5-L6 vertebrae) in a volume of $5 \mu$. CCL2 administration preceded by $\mathrm{C} 021$ injection: $\mathrm{V}$ or C021 $(30 \mu \mathrm{g} / 5 \mu \mathrm{l})$ were administered intrathecally. Then, after $15 \mathrm{~min}, \mathrm{~V}$ or CCL2 $(10 \mathrm{ng} / 5 \mu \mathrm{l})$ were injected i.t. The behavioral tests were conducted $1 \mathrm{~h}$ after chemokine injection. C021 or RS504393 injection in the STZ-induced mouse model of diabetic neuropathic pain: V, CCR4 antagonist or CCR2 antagonist were administered intrathecally $(10,20$, or $30 \mu \mathrm{g} / 5 \mu \mathrm{l}$ for C021 and $30 \mu \mathrm{g} / 5 \mu \mathrm{l}$ for RS504393) and intraperitoneally (1, 5, 10, or $20 \mathrm{mg} / \mathrm{kg}$ for $\mathrm{C} 021$ and $30 \mu \mathrm{g} / 5 \mu \mathrm{l}$ for RS504393) on day 7after STZ treatment. The behavioral tests were conducted 1, 4 and $24 \mathrm{~h}$ after these injections. Coadministration of $\mathrm{C} 021$ with opioids: V or CCR4 antagonist were administered i.t. $(30 \mu \mathrm{g} / 5 \mu \mathrm{l})$ and i.p. $(10 \mathrm{mg} / \mathrm{kg})$ on day 7 after STZ injection. Then, after $30 \mathrm{~min}$, the $\mathrm{V}$ - and C021-treated mice received a single injection of $\mathrm{V}$, morphine or buprenorphine using the following doses: morphine: i.t.: $1 \mu \mathrm{g} / 5 \mu \mathrm{l}$; i.p.: $5 \mathrm{mg} / \mathrm{kg}$; buprenorphine: i.t.: $1 \mu \mathrm{g} / 5 \mu \mathrm{l}$; i.p.: $5 \mathrm{mg} / \mathrm{kg}$. The behavioral tests were conducted $30 \mathrm{~min}$ after the administration of the opioids.

\section{Behavioral tests}

Measurement of blood glucose levels and body weight. The blood glucose concentrations and the body 
weight measurements were performed on day 7 after STZ administration using an Accu-Chek Active glucometer (Warsaw, Poland).

Tactile hypersensitivity (von Frey test). Tactile hypersensitivity was evaluated using calibrated nylon monofilaments of increasing strength (from 0.6 to $6 \mathrm{~g}$ ) (Stoelting, Wood Dale, USA). The mice were placed in plastic cages with a wire net floor $5 \mathrm{~min}$ before the experiment. The filaments were applied to the midplantar surface of the hind paws until withdrawal responses were observed (Zychowska et al., 2016; Rojewska et al., 2018). Both hind paws were tested in the same way in STZ-treated and naive mice.

Thermal hypersensitivity (cold plate test). The reactions to thermal hypersensitivity were assessed using the cold plate test (Ugo Basile, Gemonio, Italy). The mice were placed on a cold plate with a temperature of $2{ }^{\circ} \mathrm{C}$, and the latency to the elevation of the hind paw was recorded (the cut-off latency was 30 s) (Zychowska et al., 2016; Rojewska et al., 2018). In STZ-treated and naive mice, both hind paws were observed simultaneously.

Motor coordination (rotarod test). The rotarod test is a commonly used method to evaluate motor coordination in animals by assessing their ability to move efficiently as previously described (Starnowska et al., 2017). The mice were placed in a separate compartment on a horizontal rod that rotated at accelerating speed, starting at $2 \mathrm{rpm}$ and reaching $40 \mathrm{rpm}$ within $300 \mathrm{~s}$. The animals were acclimated to the apparatus and trained on the rotating rod. The main experiment was performed after the training sessions, which lasted $300 \mathrm{~s}$ each. The time until the mice fell off the rod was recorded. A rotarod test was conducted $1 \mathrm{~h}$ after drug administration. The cut-off latency was $300 \mathrm{~s}$.

\section{mRNA and protein level analysis}

The lumbar (L4-L6) regions of the spinal cord were collected after the decapitation of naive mice and mice with STZ-induced neuropathy on day 7 .

Analysis of mRNA level (RT-qPCR). Total RNA was extracted with TRIzol reagent (Invitrogen, Carlsbad, USA) as previously described (Chomczynski and Sacchi, 2006). The concentration and quality of the RNA were measured byaDeNovixDS-11 Spectrophotometer (DeNovix Inc., Wilmington, USA). The Omniscript RT Kit (Qiagen Inc., Hilden, Germany), oligo (dT16) primer (Qiagen Inc., Hilden, Germany) and RNAse inhibitor (rRNasin, Promega, Mannheim, Germany) were used for reverse transcription, which was performed using $1 \mu \mathrm{g}$ of total RNA. The obtained cDNA was diluted 1:10 with RNase-/DNase-free $\mathrm{H}_{2} \mathrm{O}$. RT-qPCR was conducted with $\sim 50 \mathrm{ng}$ of cDNA from each sample using Assay-OnDemand TaqMan probes (Applied Biosystems, Foster City, USA) and was performed in an iCycler device (Bio-Rad, Hercules, Warsaw, Poland). The following TaqMan primers were used: Mm03024075_m1 (HPRT, hypoxanthine-guanine phosphoribosyl transferase); Mm01244826_g1 (CCL17); Mm00436439_m1 (CCL22); and Mm00441243_g1 (CCL2). As in our previous study, HPRT was used as an endogenous control and an adequate housekeeping gene (Kwiatkowski et al., 2019; Pawlik et al., 2020). HPRT did not exhibit any significant changes across groups.

Analysis of protein level (Western blot). The samples were homogenized in RIPA buffer containing a protease inhibitor cocktail (Sigma-Aldrich, St. Louis, USA) and were cleared via centrifugation (30 min, 14,000 rpm, and $4{ }^{\circ} \mathrm{C}$ ). The total protein concentrations were measured using the bicinchoninic acid (BCA) method. The samples (10 $\mu \mathrm{g}$ of protein) were heated in loading buffer (4× Laemmli buffer, Bio-Rad, Warsaw, Poland) for $5 \mathrm{~min}$ at $98^{\circ} \mathrm{C}$. Electrophoresis was performed on 4-15\% TGX precast polyacrylamide gels (Bio-Rad, Warsaw, Poland). The proteins were transferred from the gels (semidry transfer, $30 \mathrm{~min}$, and $25 \mathrm{~V}$ ) to ImmunBlot PVDF membranes (Bio-Rad, Warsaw, Poland), and the membranes were blocked for $1 \mathrm{~h}$ at room temperature using $5 \%$ nonfat dry milk (Bio-Rad, Warsaw, Poland) in Tris-buffered saline with $0.1 \%$ Tween-20 (TBST). Next, the membranes were washed in TBST buffer and incubated overnight at $4{ }^{\circ} \mathrm{C}$ with the following primary antibodies: rabbit anti-CCR4 (1:750, Invitrogen, California, USA) and mouse anti-GAPDH (1:5000, Millipore, Darmstadt, Germany). Then, the membranes were washed with TBST buffer and incubated for $1 \mathrm{~h}$ at room temperature with HRPconjugated secondary antibodies (Vector Laboratories, Burlingame, USA) at a dilution of 1:5000. To dilute the primary and secondary antibodies, the SignalBoost ${ }^{\mathrm{TM}}$ Immunoreaction Enhancer Kit (Millipore, Darmstadt, Germany) solution was used. The detection of the selected proteins was performed using Clarity ${ }^{\mathrm{TM}}$ Western ECL Substrate (Bio-Rad, Warsaw, Poland) and visualized by Fujifilm LAS-4000 Fluorlmager system. The relative levels of immunoreactivity were quantified using Fujifilm MultiGauge software.

Analysis of the protein level (RayBio mouse inflammation antibody array). The samples were homogenized in 1x Cell Lysis Buffer (RayBio, Peachtree Corners, GA, USA) with a Protease Inhibitor Cocktail (Sigma-Aldrich, St. Louis, USA) and were cleared by centrifugation (30 min, $14,000 \mathrm{~g}$, and $4{ }^{\circ} \mathrm{C}$ ). The protein concentration in the supernatant was determined using the BCA Protein Assay Kit (Sigma-Aldrich, St. Louis, USA). Then, the samples were diluted with $1 \times$ Blocking Buffer to a final concentration of $250 \mu \mathrm{g}$ protein per sample. The RayBio membranes (Table 1) were blocked at room temperature and incubated with $1 \mathrm{~mL}$ of sample overnight at $4^{\circ} \mathrm{C}$. Next, the samples were decanted, and the membranes were washed three times with $2 \mathrm{~mL}$ of $1 \times$ Wash Buffer I (RayBio, Peachtree Corners, GA, USA) and two times with $2 \mathrm{~mL}$ of $1 \times$ Wash Buffer II (RayBio, Peachtree Corners, GA, USA) at room temperature. To each membrane, $1 \mathrm{~mL}$ of diluted biotinconjugated anti-cytokine antibodies (RayBio, Peachtree 
Table 1. We used the RayBio ${ }^{\circledR}$ Mouse Inflammation Antibody Array $1(40)$ - CCL2 is referred to on the array as monocyte chemotactic protein 1 (MCP-1)

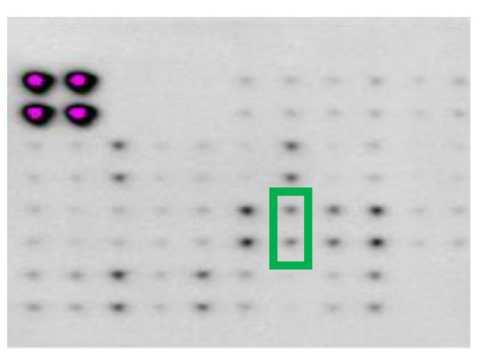

\begin{tabular}{|c|c|c|c|c|c|c|c|c|c|c|c|c|}
\hline & A & B & c & D & E & $\mathbf{F}$ & G & $\mathrm{H}$ & $\mathrm{I}$ & $\mathrm{J}$ & $\mathrm{K}$ & L \\
\hline 1 & Pos & pos & NEG & NEG & Blank & BLC & $\mathrm{CD} 30 \mathrm{~L}$ & Eotaxin & Eotaxin-2 & Fas Ligand & Fractalkine & GCSF \\
\hline 2 & pos & pos & NEG & NEG & Blank & BLC & $\mathrm{CD} 30 \mathrm{~L}$ & Eotaxin & Eotaxin-2 & Fas Ligand & Fractalkine & GCSF \\
\hline 3 & GM-CSF & IFN $\gamma$ & IL-1 $\alpha$ & IL-1 $\beta$ & IL-2 & IL-3 & IL-4 & IL-6 & IL-9 & IL-10 & IL-12p40p70 & IL-12p70 \\
\hline 4 & GM-CSF & IFNY & $\mathrm{IL}-1 \alpha$ & $\mathrm{IL}-1 \beta$ & IL-2 & IL-3 & IL-4 & IL-6 & IL-9 & IL-10 & IL-12p40p70 & IL-12p70 \\
\hline 5 & IL-13 & IL-17 & I-TAC & KC & Leptin & LIX & Lymphotactir & MCP-1 & MCSF & MIG & MIP- $1 \alpha$ & MIP- $-1 \gamma$ \\
\hline 6 & IL-13 & IL-17 & I-TAC & KC & Leptin & LIX & Lymphotactir & MCP-1 & MCSF & MIG & MIP-1 $\alpha$ & MIP- $-1 \gamma$ \\
\hline 7 & RANTES & SDF-1 & TCA-3 & TECK & TIMP-1 & TIMP-2 & TNF $\alpha$ & STNF RI & sTNF R II & Blank & Blank & POS \\
\hline 8 & RANTES & SDF-1 & TCA-3 & TECK & TIMP-1 & TIMP-2 & TNF $\alpha$ & STNF RI & STNF R II & Blank & Blank & POS \\
\hline
\end{tabular}

Corners, Georgia) were added and incubated at room temperature for $90 \mathrm{~min}$. Then, the primary antibodies were decanted, and the membranes were washed. The membranes were incubated for $2 \mathrm{~h}$ at room temperature with $2 \mathrm{~mL}$ of 1000-fold diluted HRP-conjugated streptavidin (RayBio, Peachtree Corners, GA, USA). The HRP-conjugated streptavidin was decanted, and the membranes were washed. The immunocomplexes were detected using detection buffer (RayBio, Peachtree Corners, GA, USA) and visualized using a Fujifilm LAS4000 Fluorlmager system. The relative levels of immunoreactivity were quantified using Fujifilm Image Gauge software.

\section{Data analysis}

For statistical analyses $F$ test to compare variances was performed. The behavioral and biochemical results on Fig. 1 were statistically evaluated using a $t$-test or Welch $t$-test (for single comparisons) depending on the $F$ test result. Moreover, one-way analysis of variance (ANOVA) followed by Bonferroni's post hoc test (for multiple comparisons) were used to analyze the results on Figs. 2-7. Obtained data are presented as means \pm standard error of measurement (SEM). The total number of mice for all experiments was 355 - a detailed number of used animals is presented in figure legends. All graphs were prepared using GraphPad Prism 7 software.

\section{RESULTS}

The influence of streptozotocin administration on plasma glucose concentrations, neuropathic painrelated behaviors, spinal CCL17, CCL22 and CCL2 mRNA levels and CCL2 and CCR4 protein levels measured on day 7 after STZ treatment

An increase in the plasma glucose concentration was observed on day 7 following a single STZ $(200 \mathrm{mg} / \mathrm{kg}, i$. p.) injection compared with the plasma glucose concentration in naive animals $\left(t_{14.37}=7.68\right.$, $p<0.0001$ ) (Fig. 1A). In addition, we observed the development of tactile and thermal hypersensitivity, as measured by the von Frey $\left(t_{15.78}=7.49, p<0.0001\right)$ and cold plate $\left(t_{22.00}=22.09, p<0.0001\right)$ tests, respectively (Fig. 1B, C). Moreover, we observed significant changes in the CCL2 mRNA level $\left(t_{11.51}=2.54, p=0.0266\right)$ (Fig. 1D), but not in the
CCL17 (Fig. 1E) and CCL22 (Fig. 1F) mRNA levels, compared to those in naive mice. Additionally, microarray analysis showed the upregulation of the CCL2 protein level in the spinal cord $\left(t_{15.57}=3.56\right.$, $p=0.0027$ ) (Fig. 1G). Moreover, we demonstrated that there were no changes in the levels of CCR4 in STZtreated animals compared to this in naive mice, as measured by Western blot analysis (Fig. 1H).

\section{The effect of a single intrathecal administration of recombinant CCL2 protein preceded by the injection of $\mathrm{C} 021$ in naive mice.}

Our results indicated that a single intrathecal injection of C021 (30 $\mu \mathrm{g} / 5 \mu \mathrm{l}$; Fig. 2A) had no effect on tactile and thermal hypersensitivity, as measured by the von Frey (Fig. 2B) and cold plate (Fig. 2C) tests, $1 \mathrm{~h}$ after administration. We observed strong tactile and thermal hypersensitivity $1 \mathrm{~h}$ after the injection of CCL2, as measured by the von Frey $\left(F_{3,20}=19.27, p<0.0001\right)$ (Fig. 2B) and cold plate $\left(F_{3,20}=20.67, p<0.0001\right)$ (Fig. 2C) tests, respectively. The injection of $\mathrm{C} 021$ $(30 \mu \mathrm{g} / 5 \mu \mathrm{l}) 15 \mathrm{~min}$ before the intrathecal injection of recombinant CCL2 protein prevented the chemokineinduced hypersensitivity observed in the von Frey and cold plate tests (Fig. 2B, C).

\section{The influence of a single intrathecal injection of C021 or RS504393on the neuropathic pain-related behavior measured on day 7 after STZ administration}

We observed in the von Frey test that $\mathrm{C} 021$ administered intrathecally $(10,20$, or $30 \mu \mathrm{g} / 5 \mu \mathrm{l}$; Fig. $3 \mathrm{~A})$ diminished the tactile hypersensitivity measured $1 \mathrm{~h}\left(F_{3,27}=12.77\right.$, $p<0.0001)$ and $4 \mathrm{~h}\left(F_{3,28}=4.60, p<0.0097\right)$ after injection compared with that in the $V$-treated group (Fig. 3A). This effect was still observed $24 \mathrm{~h}$ after the administration of a dose of $30 \mu \mathrm{g} / 5 \mu \mathrm{l}$. In the cold plate test, the intrathecal administration of $\mathrm{C} 021$ significantly reduced the thermal hypersensitivity $1 \mathrm{~h}\left(F_{3,27}=12.77\right.$, $p<0.0001)$ and $4 \mathrm{~h}\left(F_{3,28}=4.60, p<0.0097\right)$ after injection compared with that in the $V$-treated group (Fig. 3B). The effect lasted $24 \mathrm{~h}$ for doses of 20 and $30 \mu \mathrm{g} / 5 \mu \mathrm{l}$. We observed that RS504393 administered intrathecally $(30 \mu \mathrm{g} / 5 \mu \mathrm{l})$ did not influence tactile and thermal hypersensitivity, as measured 1,4 and $24 \mathrm{~h}$ after injection, compared with that in the $\mathrm{V}$-treated group (Fig. 3C D). 

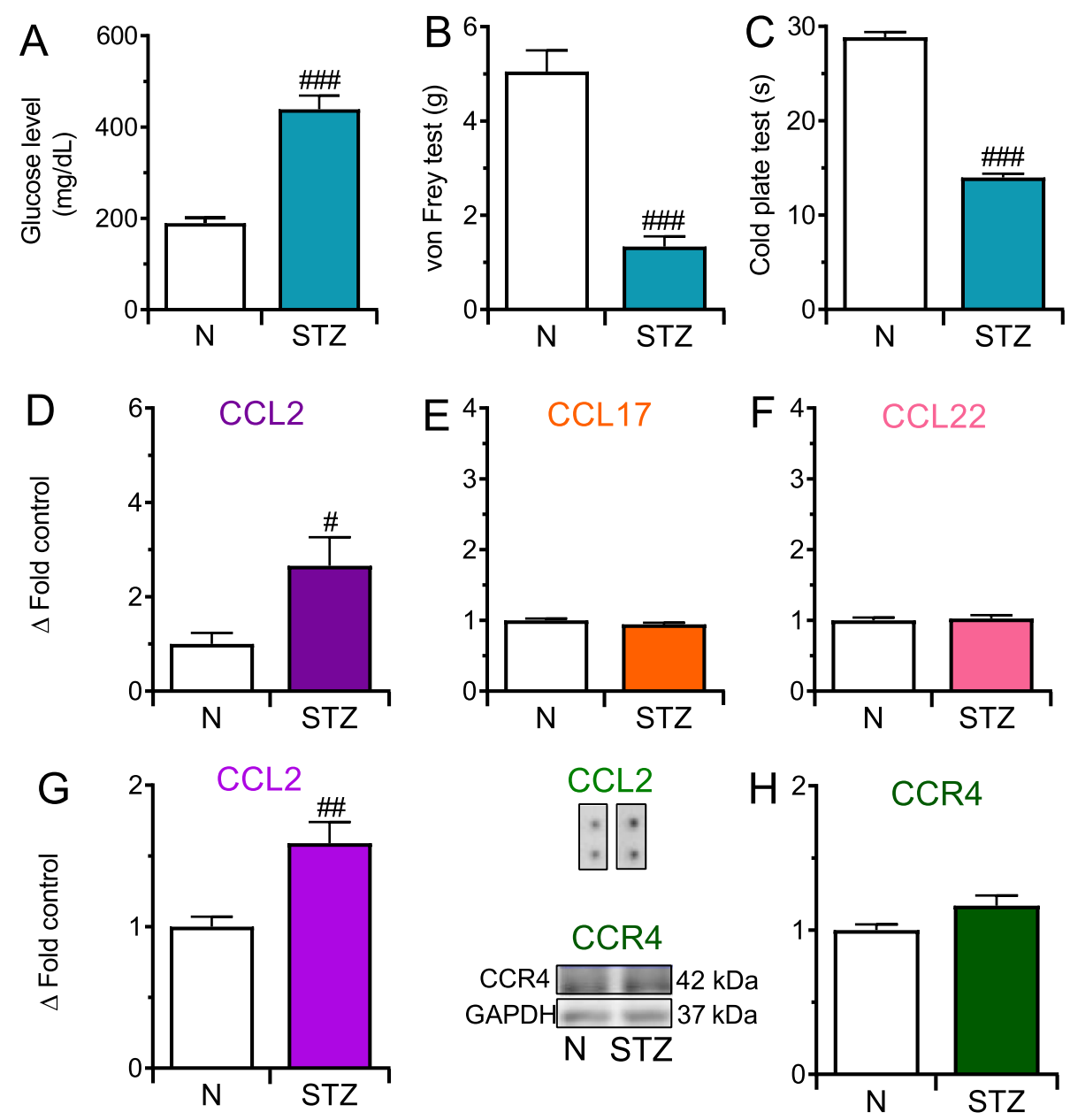

Fig. 1. Changes in the pain-related behavior caused by hyperglycemia together with the changes in the spinal mRNA levels of CCL2, CCL17 and CCL22 and in the protein levels of CCL2 and CCR4 7 days after STZ treatment in mice. The effects of a single STZ injection on plasma glucose (A), mechanical (von Frey test; B) and thermal (cold plate test; C) hypersensitivity, mRNA levels of CCL2 (D), CCL17 (E) and CCL22 (F) (RT-qPCR analysis) and protein levels of CCL2 (G, protein microarray analysis) and CCR4 (H, Western blot analysis). Data are presented as the fold change relative to control mice (naive) \pm SEM, total number of animals: 66 mice: A-F, naive, $n=7-$ 12 mice per group; STZ, $n=12$ mice per group; G, naive, $n=12$ mice per group; STZ, $n=12$ mice per group and $\mathrm{H}$, naive, $n=8$; STZ, $n=10$ mice per group. The results were statistically evaluated

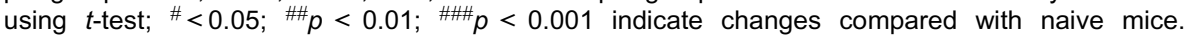
Abbreviations: $\mathrm{N}$, naive; STZ, streptozotocin.

The influence of a single intrathecal injection of $\mathrm{C} 021$ on the effectiveness of morphine and buprenorphine measured on the 7th day after STZ treatment

A single intrathecal C021 injection $(30 \mu \mathrm{g} / 5 \mu \mathrm{l}$; Fig. 4A) significantly attenuated the STZ-induced tactile hypersensitivity, as measured by the von Frey test $\left(F_{3,24}=52.03, p<0.0001 \quad\right.$ Fig. $4 \mathrm{~B} ; \quad F_{3,25}=59.87$, $p<0.0001 \mathrm{Fig} .4 \mathrm{D}$ ), compared to that in the V-treated group. Similarly, in the cold plate test, we observed a reduction in thermal hypersensitivity in the C021-treated mice $\quad\left(F_{3,26}=144.30, \quad p<0.0001 \quad\right.$ Fig. 4C; $F_{3,26}=232.90, \quad p<0.0001$ Fig. 4E). Tactile and thermal hypersensitivity were also significantly reduced after a single i.t. injection of morphine $(1 \mu \mathrm{g} / 5 \mu \mathrm{l})$ or buprenorphine $(1 \mu \mathrm{g} / 5 \mu \mathrm{l})$, as measured by the von Frey (Fig. 4B, D) and cold plate tests (Fig. 4C, E). The intrathecal injection of $\mathrm{C} 021$ enhanced the effectiveness of both morphine and buprenorphine in the von Frey (Fig. 4B, D) and cold plate tests (Fig. 4C, E).

The influence of single intraperitoneal injection of $\mathrm{C021}$ or RS504393 on neuropathic pain-related behavior on the 7th day after STZ treatment

We observed in the von Frey test that $\quad 021$ administered intraperitoneally $(1,5,10$, or $20 \mathrm{mg} / \mathrm{kg}$; Fig. 5A) diminished tactile hypersensitivity $1 \mathrm{~h}$ $\left(F_{4,32}=30.52, \quad p<0.0001\right)$ after treatment in a dose-dependent manner. The effect was not observed after $4 \mathrm{~h}$. In the cold plate test, the most effective intraperitoneal doses were 10 and $20 \mathrm{mg} / \mathrm{kg}$, and these doses led to the attenuation of thermal hypersensitivity $1 \mathrm{~h} \quad\left(F_{4,32}=\right.$ 48.06, $p<0.0001$ ) after injection (Fig. 5B); however, this effect was not observed after $24 \mathrm{~h}$ for both doses. We revealed that the intraperitoneal injection of RS504393 $(10 \mu \mathrm{g} / \mathrm{kg})$ did not affect tactile and thermal hypersensitivity, as measured 1, 4 and $24 \mathrm{~h}$ after injection, compared with that in the $\mathrm{V}$-treated group (Fig. 5C, D).

\section{The effect of a single} intraperitoneal injection of $\mathrm{C021}$ on the effectiveness of morphine and buprenorphine measured on the 7th day after STZ treatment

A single intraperitoneal injection of C021 (10 mg/kg; Fig. 6A) significantly attenuated the STZ-induced tactile hypersensitivity $1 \mathrm{~h}$ after administration, as measured by the von Frey test $\left(F_{3,27}=60.54, p<0.0001\right.$ Fig. $6 \mathrm{~B}$; $\left.F_{3,22}=71.55, p<0.0001 \mathrm{Fig} .6 \mathrm{D}\right)$, compared to that in the V-treated animals. Likewise, we observed a reduction in thermal hypersensitivity in the cold plate test $\left(F_{3,24}=56.73, p<0.0001\right.$ Fig. $6 \mathrm{C} ; F_{3,21}=154.10$, $p<0.0001$ Fig. 6E). Hypersensitivity was also significantly diminished after a single i.p. injection of morphine $(5 \mathrm{mg} / \mathrm{kg})$ or buprenorphine $(5 \mathrm{mg} / \mathrm{kg})$, as measured by the von Frey (Fig. 6B, D) and cold plate tests (Fig. 6C, E). The intraperitoneal injection of $\mathrm{C} 021$ enhanced the effectiveness of both morphine and buprenorphine in the von Frey (Fig. 6B, D) and cold plate tests (Fig. 6C, E). 


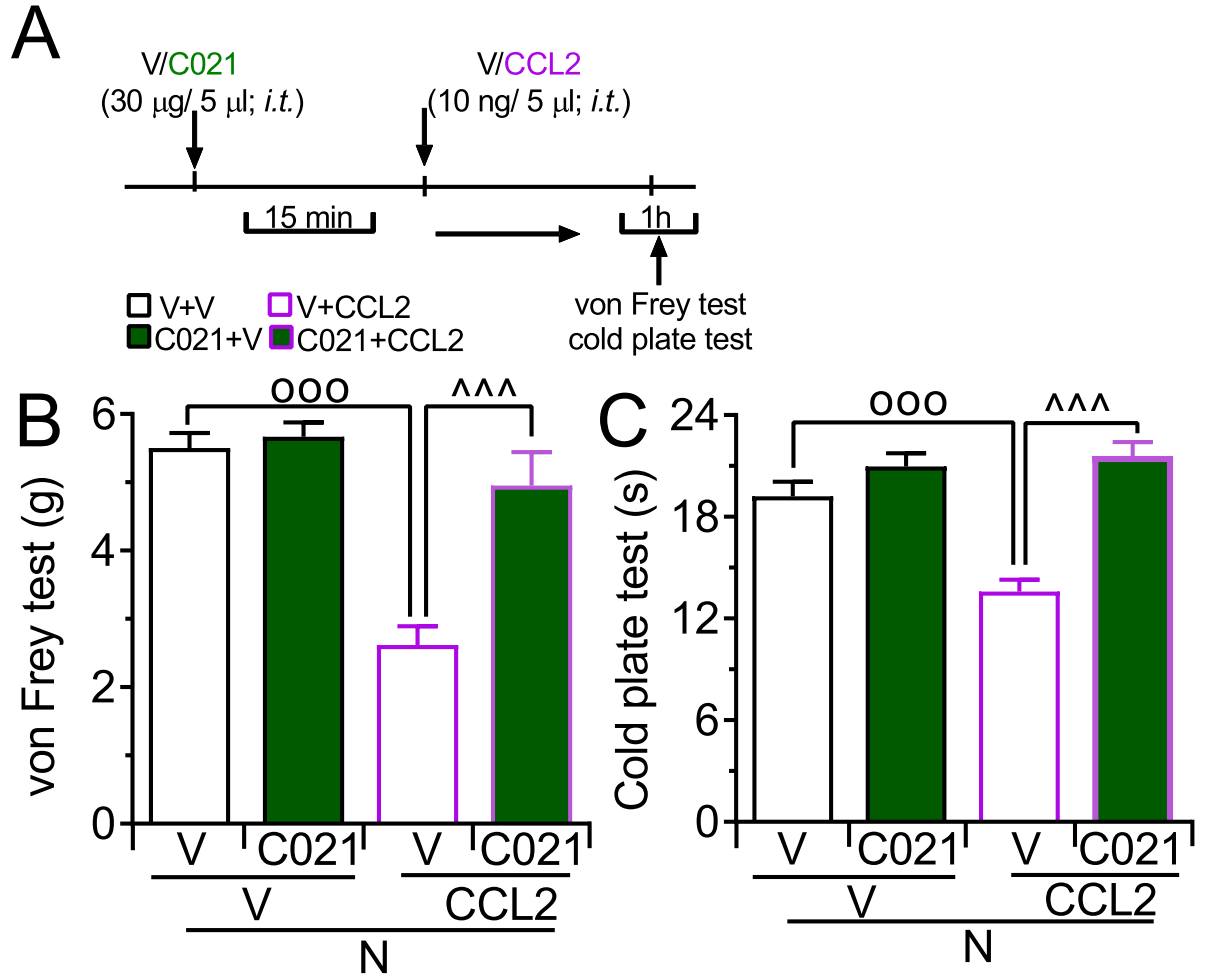

Fig. 2. The pronociceptive effect of a single intrathecal injection of CCL2 diminished by the previous intrathecal injection of $\mathbf{C 0 2 1}$ in naive mice. Behavioral tests were performed $1 \mathrm{~h} 15 \mathrm{~min}$ after $V$ or C021 $(30 \mu \mathrm{g} / 5 \mu \mathrm{l})$ treatment, which means $1 \mathrm{~h}$ after CCL2 (10 $\mathrm{ng} / 5 \mu \mathrm{l})$ administration A. Tactile (B, von Frey test) and thermal (C, cold plate test) hypersensitivity was measured. Data are presented as the mean \pm SEM, total number of animals: 24 mice: $(\mathbf{B}, \mathbf{C}) n=6$ mice per group. The results were evaluated with the use of one-way ANOVA followed by Bonferroni's multiple comparisons post hoc test of selected pairs at the indicated time points. ${ }^{\circ 00} p<0.001$ indicates differences between the $\mathrm{V}+\mathrm{V}$ and $\mathrm{V}+\mathrm{CCL}$-treated naive mice; ${ }^{\wedge \wedge}{ }^{\wedge} p<0.001$ indicates differences between the $\mathrm{V}$ + CCL2- and C021 + CCL2-treated naive mice. Abbreviations: C021, C021 dichydrochloride (CCR4 antagonist); $\mathrm{N}$, naive; $\mathrm{V}$, water for injection.

\section{The effect of a single intrathecal and intraperitoneal injection of $\mathrm{C} 021$ on motor coordination measured on the 7th day after STZ treatment}

A single intrathecal $(30 \mu \mathrm{g} / 5 \mu \mathrm{l}$; Fig. $7 \mathrm{~A})$ and intraperitoneal (10 mg/kg; Fig. 7B) C021 injection significantly improved motor coordination in STZ-treated animals, as measured by the rotarod test, while Vtreated mice exhibited significant impairment of motor function compared with naive animals $\left(F_{2,29}=6,70\right.$, $p=0.0040$ for i.t and $F_{2,21}=4.54, p=0.0230$ for i.p.).

\section{DISCUSSION}

The present study is the first to demonstrate the importance of CCR4 as one of the crucial receptors involved in the pathogenesis of neuropathic pain in diabetes. In a STZ-induced mouse model of diabetic neuropathy, we proved that the mRNA and protein levels of CCL2 are elevated in the spinal cord on day 7 , when strong tactile and thermal hypersensitivity has developed. Moreover, in naive mice, the CCR4 antagonist is able to block the pronociceptive properties of intrathecally injected CCL2. Importantly, our research provides the first evidence that in STZ-induced neuropathy, both the intrathecal/intraperitoneal administration of C021 (CCR4 antagonist) diminishes tactile and thermal hypersensitivity in a dosedependent manner, beneficially effects motor coordination, and enhances the analgesic properties of morphine and buprenorphine. Our results provide a novel basis for the further evaluation of the potential use of CCR4 as a target for the treatment of diabetic neuropathy and suggest spinal CCL2/CCR4 signaling as an important process for diabetic neuropathy development and opioid effectiveness.

Streptozotocin-induced diabetes is a well-established animal model used in studies of neuropathic pain (Morgado et al., 2011; Pabreja et al., 2011; Zychowska et al., 2015, 2016, 2017; Castany et al., 2016; Kou et al., 2016; Rojewska et al., 2018). The hyperglycemic states that occur in diabetes are responsible for Schwann cell metabolic activity disruption and myelin degeneration and, consequently, neuropathic pain development (Mizisin, 2014). The response to noxious stimuli is transmitted by lightly myelinated $A \delta$ and unmyelinated $\mathrm{C}$ fibers, while the reaction to nonnoxious stimuli is conducted by highly myelinated $A \beta$ fibers (Neumann et al., 1996). Moreover, high blood glucose level contributes to the development of inflammation. The release of inflammatory mediators, such as interleukins and chemokines, initiates the immune response. The neuroinflammatory process at the spinal cord level can cause the activation of glial cells, which can release many pronociceptive factors in an uncontrolled manner. In summary, the pathophysiology of diabetic neuropathic pain is complex and includes peripheral and central neuronal changes as well as neuroimmune interactions, which become more prominent during inflammatory reactions (Safieh-Garabedian et al., 2019). In streptozotocin-induced diabetes, the increased blood glucose concentration correlates with long-lasting hypersensitivity to mechanical and thermal stimuli (Zychowska et al., 2013a), and this correlation is in agreement with our obtained results. Currently, an increasing number of works indicate the important role of neuroimmunological changes in neuropathy development (Zychowska et al., 2013a, 2015; Rojewska et al., 2018); however, the role of CCR4 in diabetes still needs to be clarified, which is why this receptor became the subject of our research.

There is growing evidence that suggests the functional involvement of the CCR4-CCL17/CCL22/ 

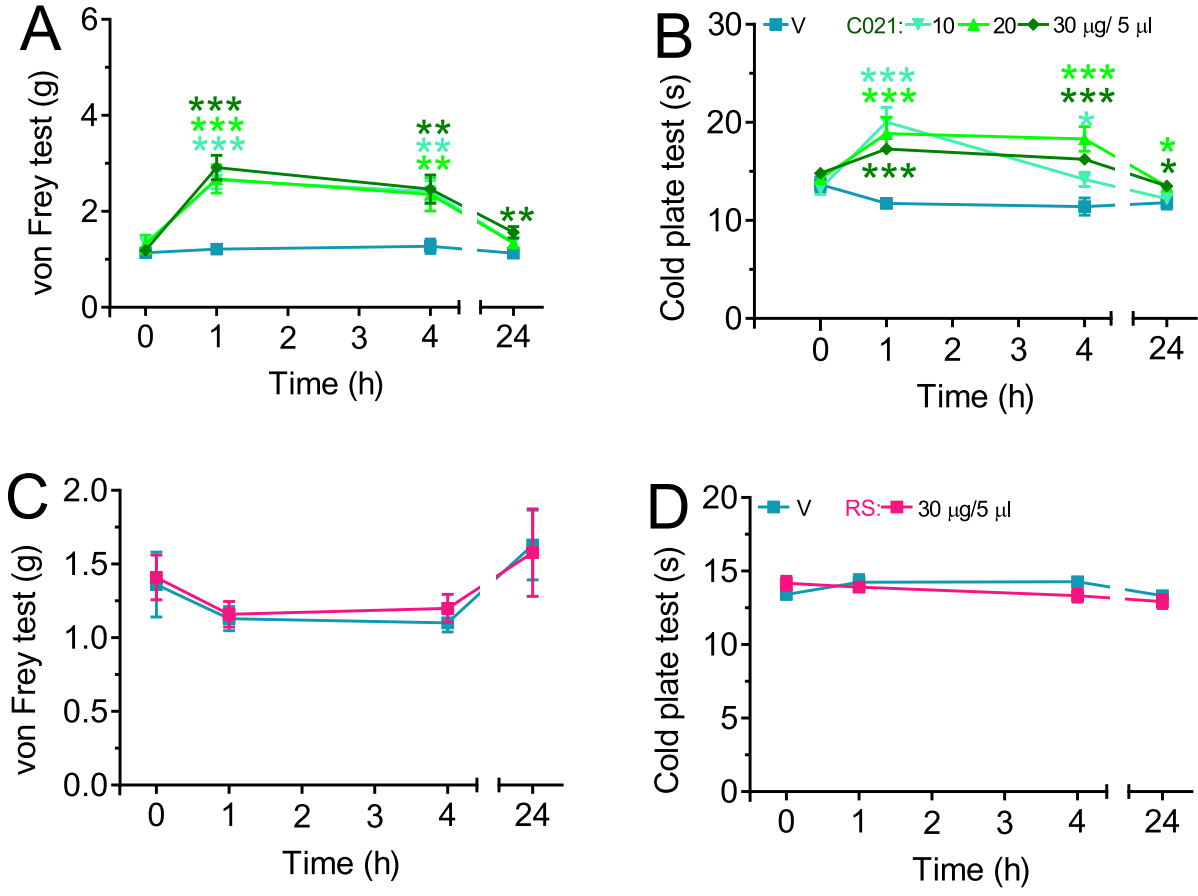

Fig. 3. The intrathecal injection of $\mathrm{C021}$ diminished hypersensitivity in a dose-dependent manner 7 days after STZ treatment in mice. Effects of single injections of V, C021 or RS (C021: 10, 20 , or $30 \mu \mathrm{g} / 5 \mu \mathrm{l}$; RS: $30 \mu \mathrm{g} / 5 \mu \mathrm{l}$ ) on mechanical (von Frey test; A, C) and thermal (cold plate test; B, D) hypersensitivity, as measured at 1, 4 and $24 \mathrm{~h}$ following antagonist injection. Data are presented as the mean \pm SEM, total number of animals: 52 mice: (A, B) $n=6-8$ mice per group; (C, D) $n=9-10$ mice per group. The results were evaluated using one-way ANOVA followed by Bonferroni's test for multiple comparisons. ${ }^{*} p<0.05,{ }^{* *} p<0.01$, and ${ }^{* * *} p<0.001$ indicate significant differences between the $\mathrm{V}$ treated and C021-treated STZ-exposed animals. Abbreviations: V, water for injection or DMSO (control group for RS504393); C021, C021 dichydrochloride (CCR4 antagonist); RS, RS504393 (CCR2 antagonist); STZ, streptozotocin.

CCL2 axis in the pathogenesis of many diseases. The significance of CCR4 during the development of asthma (Zhang et al., 2017), multiple sclerosis (Moriguchi et al., 2016; Jafarzadeh et al., 2017; Ruland et al., 2017; Scheu et al., 2017), and dermatitis (Matsuo et al., 2018) has been described. Recently it has been shown that blockade of the CCR4 might be a promising strategy in patients with hepatocellular carcinoma (Cheng et al., 2017), glioblastoma (Jacobs et al., 2010), prostate, ovarian, lung and breast cancers (Zou et al., 2005; Li et al., 2012; Maolake et al., 2017). It has been indicated that CCR4 promotes tumor growth and metastasis (Cheng et al., 2017). Moreover, in vitro data have shown that CCL2 not only increases the expression of CCR4 in cancer cells (Maolake et al., 2017), but also induces the migration of lymphocytes toward melanoma (Zhang et al., 2006). In 2017, Kiguchi et al. showed for the first time altered spinal expression of CCR4 in diabetic monkeys; however, the role of CCR4 in nociceptive transmission has not been studied thus far (Kiguchi et al., 2017). CCR4 is present in many cells of the nervous system, including both neuronal (Meucci et al., 1998) and nonneuronal (e.g. microglia, astroglia, dendritic cells, macrophages, lymphocytes, basophils, natural killer cells, and platelets) (Abi-Younes et al., 2001; Flynn et al., 2003; Stolberg et al., 2011; Pease and Horuk, 2014) cells. CCR4 has two main ligands, CCL17 and CCL22 (Imai et al., 1997; Yoshie and Matsushima, 2015; Scheu et al., 2017), which, as we have shown, exhibit strong pronociceptive properties in naive mice (Bogacka et al., 2020). CCL17 can be produced by microglia (Klein et al., 2017), thymus and peripheral blood mononuclear cells (Imai et al., 1997; Nomiyama et al., 1997), dendritic cells (Sallusto et al., 1999; Alferink et al., 2003) and neurons (Fülle et al., 2018). The level of CCL17 is enhanced in patients suffering from fibromyalgia (Garcia et al., 2014), diabetic retinopathy (Dai et al., 2014) and in animal models of multiple sclerosis (Ruland et al., 2017; Scheu et al., 2017). CCL22 is mainly released by macrophages and microglia (Yamashita and Kuroda, 2002; Scheu et al., 2017), and increased levels of CCL22 have been described in animal models of asthma (Zhang et al., 2017), dermatitis (Matsuo et al., 2018) and multiple sclerosis (Moriguchi et al., 2016; Ruland et al., 2017). However, at the spinal cord level, we did not observe changes in the mRNA levels of CCL17 and CCL22 after streptozotocin administration, so it seems that their central role is not crucial in mouse models of diabetes. However, in the periphery, the importance of CCL17 and CCL22 during tissue repair in diabetes was recently proven (Barros et al., 2019). Around $80 \%$ of people with diabetes suffer from a various skin disorders (Demirseren et al., 2014). Wound healing is a process that involves many inflammatory mediators and is one of the serious long-term complications associated with this metabolic disease. In 2019, Barros et al. showed that the CCR4/CCL17/CCL22 axis is engaged in regulatory $T$ cell recruitment and activation in inflamed skin. The results of that study provide evidence that $\mathrm{CCR} 4^{-1-}$ diabetic mice displayed an increase in collagen fiber deposition (Barros et al., 2019). However, there are evidences that CCR4-deficient mice are prone to autoimmune disorders because thymocytes do not undergo efficient clonal deletion and, as a consequence, autoreactive $T$ cells are accumulated in the periphery (Hu et al., 2015). Therefore, it is necessary to have in mind that CCR4 blockade, except significant analgesic benefits and promotion of wound healing process under diabetic neuropathy, may act like a double-edged sword. In reference to T cells importance, CCR4 is expressed by Th2 cells and it is worth to mention that diabetes can be mediated by Th1 (Von Herrath and Oldstone, 1997), Th2 (Anderson et al., 1993) or both Th1/Th2 cells (Azar et al., 1999). These populations are known to be 
A
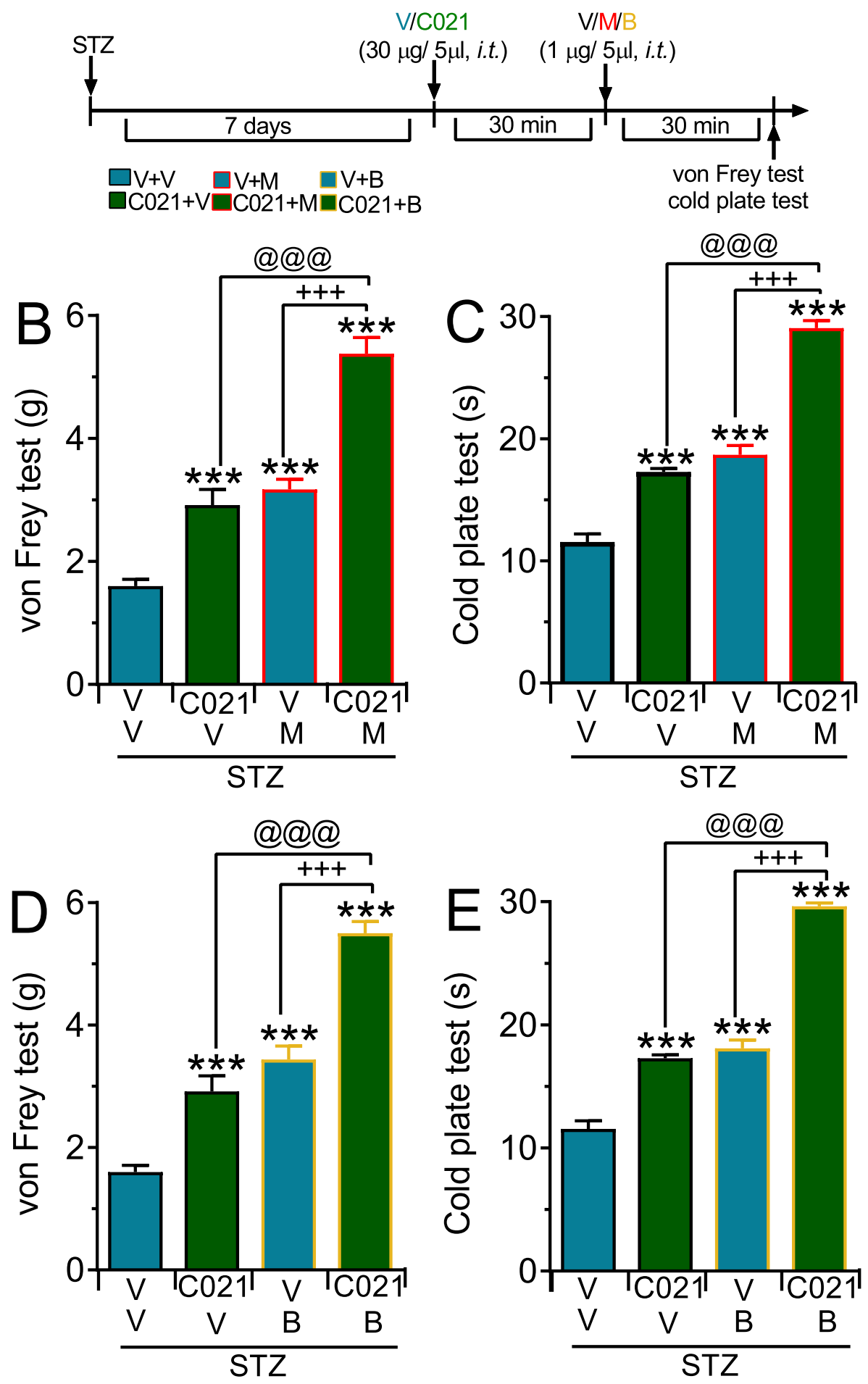

Fig. 4. The single intrathecal injection of $\mathrm{C} 021$ enhanced the effectiveness of morphine and buprenorphine 7 days after STZ treatment in mice. Animals treated with a single injection of $\mathrm{V}$ or $\mathrm{C} 021$ $(30 \mu \mathrm{g} / 5 \mu \mathrm{l})$ received a single dose of $\mathrm{V}, \mathrm{M}(1 \mu \mathrm{g} / 5 \mu \mathrm{l})$ or $\mathrm{B}(1 \mu \mathrm{g} / 5 \mu \mathrm{l})$ after $30 \mathrm{~min}$, and $30 \mathrm{~min}$ later, the behavioral tests were conducted. Data are presented as the mean \pm SEM, total number of animals: 54 mice: (B, C) $n=6-8$ mice per group; (D, E) $n=6-8$ mice per group. The results were analyzed using one-way ANOVA with Bonferroni's multiple comparisons test. ${ }^{* \star *} p<0.001$ indicates changes compared with the V + V-treated STZ-exposed mice; @@@ $p<0.001$ indicates differences between the $\mathrm{C} 021+\mathrm{V}$ - and $\mathrm{C} 021+\mathrm{M} / \mathrm{B}$-treated STZ-exposed mice; ${ }^{++}{ }^{+} p<0.001$ indicates differences between the $\mathrm{V}+\mathrm{M} / \mathrm{B}$ - and $\mathrm{C} 021+\mathrm{M} / \mathrm{B}$-treated STZ-exposed mice. Abbreviations: B; buprenorphine; C021, C021 dichydrochloride (CCR4 antagonist); M, morphine; STZ, streptozotocin; V, water for injection. implicated in the initiation and progression of the diabetes, mostly because of disrupted balance of their regulatory cytokines (Azar et al., 1999). Accordingly, it might seem that blockade of CCR4 in Th2 cells could have a negative effect under diabetes, since this cells were generally regarded as anti-inflammatory. However, Th2 and their mediators were shown to be involved in pathogenesis of diabetes through support of pancreatic mononuclear-cell infiltration and acceleration of $\beta$ islet cell destruction (Azar et al., 1999). Therefore it is possible, that CCR4 blockade in diabetes would also help to restore balance between Th1/Th2 mediators. Besides, in progression of neuropathy an increasing role has been attributed to microglia and macrophages cells. What is significant to mention, CCR4 can be also expressed by those cells (Flynn et al., 2003). It is currently known that microglia is important in the development of diabetic neuropathic pain (Zychowska et al., 2016). Moreover, in our previous study we have shown that $\mathrm{C} 021$ administration can decrease level of IBA-1-positive cells both in central and peripheral nervous system, what leads to decrease of painful symptoms evoked by chronic constriction injury (Bogacka et al., 2020). This results additionally support our hypothesis that blockade of CCR4 on microglia may have beneficial effect in the treatment of diabetes-based neuropathy.

It seems that another important ligand for CCR4 is CCL2, which until now, was considered to be the main ligand of CCR2. CCL2 is a key chemoattractant molecule for leucocytes, and it principally recruits monocytes and, to a lesser extent, memory $\mathrm{T}$ cells and dendritic cells to the sites of inflammation (Graves et al., 1999; Sorensen et al., 2004; Deshmane et al., 2009; McMillin et al., 2014). After sciatic nerve ligation in rats, the repeated intrathecal administration of a CCR2 antagonist effectively reduced neuropathic pain symptoms (Kwiatkowski et al., 

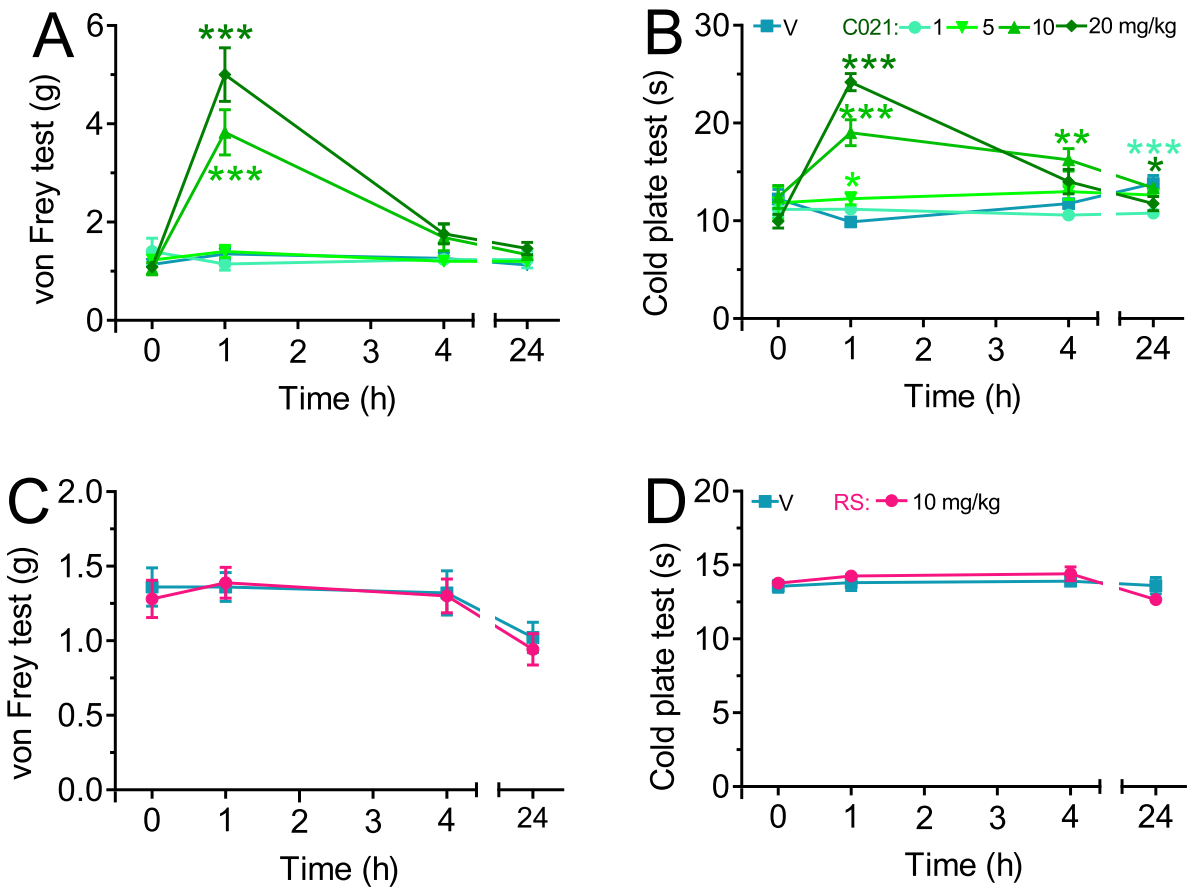

Fig. 5. Intraperitoneally injected C021 diminished hypersensitivity in a dose-dependent manner 7 days after STZ treatment in mice. Effects of a single injection of V, C021 or RS (C021: $1,5,10$, or $20 \mathrm{mg} / \mathrm{kg}$; RS: $10 \mathrm{mg} / \mathrm{kg}$ ) on mechanical (von Frey test; A, C) and thermal (cold plate test; B, D) hypersensitivity, as measured at 1,4 and $24 \mathrm{~h}$ following antagonist administration. Data are presented as the mean \pm SEM, total number of animals: 60 mice: (A, B) $n=5-8$ mice per group; (C, D) $n=7-10$ mice per group. The results were evaluated using one-way ANOVA followed by Bonferroni's test for multiple comparisons. ${ }^{*} p<0.05$, ${ }^{* *} p<0.01$, and ${ }^{* * *} p<0.001$ indicate significant differences between the V-treated and C021-treated animals after treatment with STZ. Abbreviations: V, water for injection or DMSO (control group for RS504393); C021, C021 dichydrochloride (CCR4 antagonist); RS, RS504393 (CCR2 antagonist); STZ, streptozotocin.

2017); however, the pain was not completely mitigated. Moreover, in a model of osteoarthritis, CCR2-knockout mice still had transient distal mechanical hypersensitivity (Miller et al., 2012). Importantly, single intrathecal and intraperitoneal injections of a CCR2 antagonist, in contrast to injections of a CCR4 antagonist, do not relieve hypersensitivity in diabetes. A few studies suggested that CCL2 also induced effects through CCR4 (Graves et al., 1999; McMillin et al., 2014), which is in agreement with our behavioral results showing that the CCR4 antagonist can partly diminish the CCL2 pronociceptive properties after its intrathecal administration in naive mice. In the diabetic model, we demonstrated the spinal upregulation of CCL2, which is why this chemokine seems to be an important mediator of nociceptive transmission via CCR2 and CCR4. Our data provide evidence that even a single intrathecal injection of C021 can effectively diminish pain-related behavior on day 7 of STZ-induced neuropathy in mice, when we observed fully developed hypersensitivity. Furthermore, a single intraperitoneal injection of C021 successfully diminished the neuropathic pain-related symptoms in diabetic neuropathy. Interestingly, our results provide proof that in diabetes, CCR4 blockade is more effective than CCR2 blockade. It is known that during diabetes, the deterioration of various motor skills can be observed (Pfützner et al., 2011). Importantly, patients with this disease show slower walking velocity and shorter stride length and might be more susceptible to injuries or fractures (Mueller et al., 1994). One of the reasons for these complications is nerve damage, which might accompany diabetes (Rojas et al., 2018). In our study, we showed that a single i.t. and i.p. injection of $\mathrm{C} 021$ improved the locomotor activity of STZ-treated animals, which we could observe by prolonged persistence on rotating rods. All the results we obtained suggest that CCR4 is an important target for diabetic neuropathy management; however, the exact molecular mechanism needs future investigation.

Given the high prevalence of pain experienced by diabetic patients and the fact that chemokine and opioid receptors may crosstalk, we found it essential to know whether the blockade of CCR4 can influence opioid effectiveness. It is known from clinical (PrzeklasaMuszynska and Dobrogowski, 2011) and experimental (Zurek et al., 2001; Zychowska et al., 2013a, 2017; Rojewska et al., 2018) studies that diabetic neuropathic pain management is not easy due to the relatively low effectiveness of opioids against this pain. Many studies, including these regarding diabetes, suggest that altered neuroimmunological interactions are responsible for weaker opioid analgesia. In models of neuropathic pain of different etiologies, it has been shown that pronociceptive interleukins (IL-1beta, IL-6, and IL-18) (Zanjani et al., 2006; Mika, 2008; Chen et al., 2012; Pilat et al., 2015, 2016) and chemokines (CCL1, CCL2, CCL3, CCL4, CCL5, CCL7, CCL9, CCL17 and CCL22) (Kwiatkowski et al., 2016, 2019; Zychowska et al., 2017; Rojewska et al., 2018; Bogacka et al., 2020) are involved in this phenomenon. Moreover, the literature data give many evidences that some of these cytokines also decrease the analgesic effects of opioids (Szabo et al., 2002; Chen et al., 2007; Pilat et al., 2015, 2016; Zychowska et al., 2017; Kwiatkowski et al., 2019; Pawlik et al., 2020). Additionally, beneficial effects of immunomodulators and glial inhibitors, such as pentoxyphylline and minocycline, on opioid effectiveness in neuropathy have already been shown (Mika et al., 2013; Zychowska et al., 2013a, 2016; Rojewska et al., 2014; Piotrowska et al., 2016b). These studies have indicated that the effectiveness of mentioned substances is due to their beneficial effects on microglia cells, which are strongly activated in neuropathy (Ferrini et al., 2013; Mika et al., 2013; Kwiatkowski and Mika, 2018). As we mention, our 

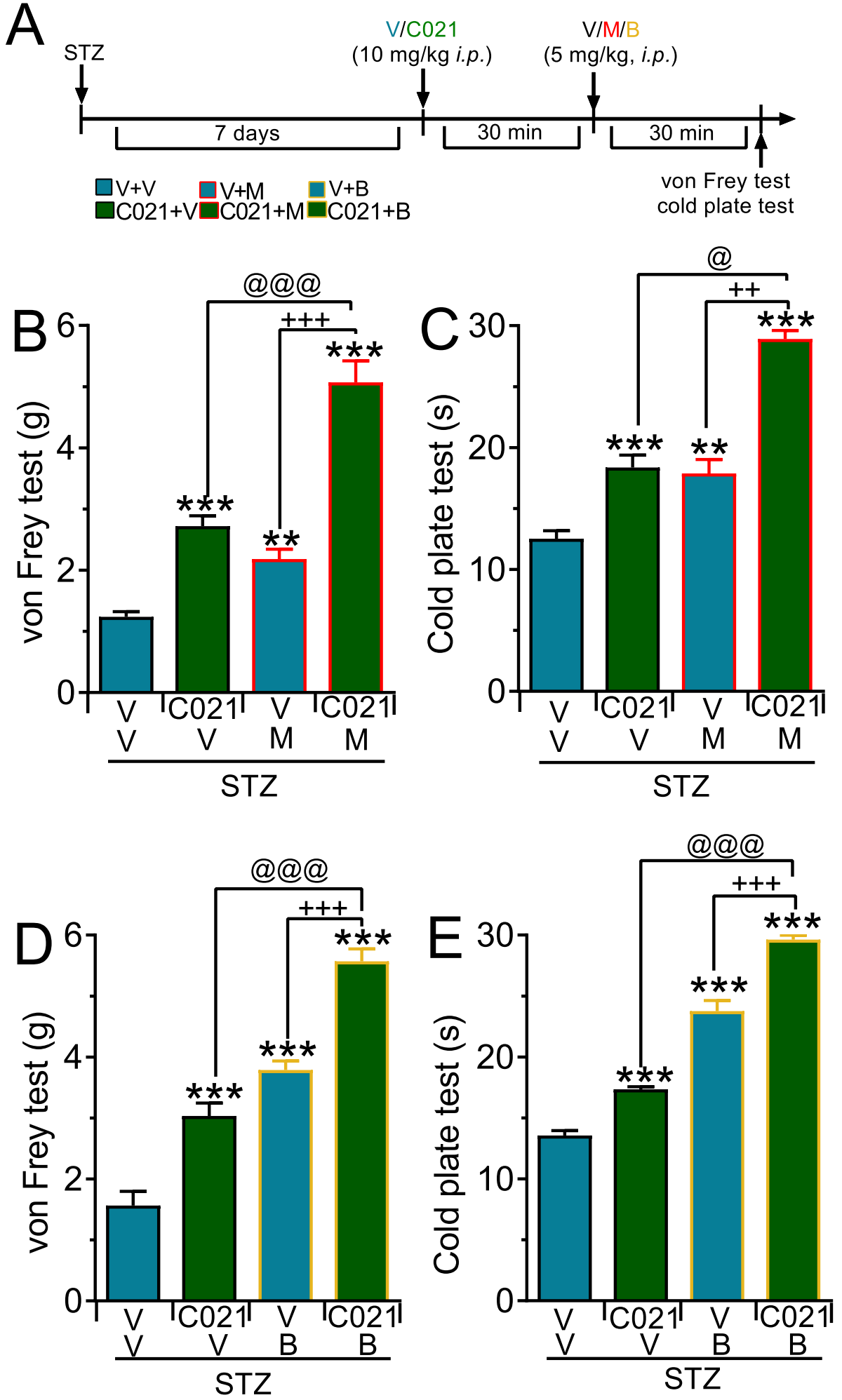

Fig. 6. The single intraperitoneal injection of C021 enhanced the effectiveness of morphine and buprenorphine 7 days after STZ treatment in mice. Animals treated with a single injection of $\mathrm{V}$ or $\mathrm{C} 021$ $(10 \mathrm{mg} / \mathrm{kg})$ received a single dose of $\mathrm{V}, \mathrm{M}(5 \mathrm{mg} / \mathrm{kg})$ or $\mathrm{B}(5 \mathrm{mg} / \mathrm{kg})$ after $30 \mathrm{~min}$, and $30 \mathrm{~min}$ later, the behavioral tests were conducted. Data are presented as the mean \pm SEM, total number of animals: 51 mice: (B, C) $n=7-8$ mice per group; (D, E) $n=5-7$ mice per group. The results were analyzed using one-way ANOVA with Bonferroni's multiple comparisons test. ${ }^{* *} p<0.01 ;{ }^{* * *} p<0.001$ indicate differences compared with the V + V-treated STZ-exposed mice; ${ }^{\circledR} p<0.05 ;{ }^{@ @ @ ~} p<0.001$ indicate differences between the C021 + V- and C021 + M/B-treated STZ-exposed mice; ${ }^{++} p<0.01$; ${ }^{++}+p<0.001$ indicate differences between the $\mathrm{V}+\mathrm{M} / \mathrm{B}-$ and $\mathrm{C} 021+\mathrm{M} / \mathrm{B}$-treated STZ-exposed mice. Abbreviations: B; buprenorphine; C021, C021 dichydrochloride (CCR4 antagonist); M, morphine; STZ, streptozotocin; V, water for injection. previous studies confirmed the strong activation of microglia under diabetic neuropathy (Zychowska et al., 2013a). CCR4 expression on microglia/macrophages was recently suggested to be responsible for pro-inflammatory polarization of these cells (Chen et al., 2019). This corresponds well with our results showing, that in rats after sciatic nerve ligation CCR4 blockade reduced the level of microglia/macrophages in the spinal cord and DRG (Bogacka et al., 2020). Similarly, also antagonists of CCR2 (Kwiatkowski et al., 2017) and CCR5 (Kwiatkowski et al., 2016) enhanced morphine analgesia in a nerve injuryinduced model of neuropathy by reducing microglia/macrophages level. Other data give evidence that the CCL2, a key mediator of spinal microglial activation, is likewise responsible for lower opioid efficacy in naive animals (Zhao et al., 2012). This is in agreement with our results showing that 021 prevents CCL2 upregulation in mouse model of neuropathy, which can be one of the mechanism of its beneficial effects (Bogacka et al., in press). The data from our research provide the first evidence that intrathecal and intraperitoneal injections of C021 enhanced the effectiveness of morphine and buprenorphine in diabetic neuropathy. This is an important observation from a clinical point of view; however, the molecular mechanism still needs further investigations. Based on literature (Zhang et al., 2003, 2004; Brack et al., 2004; Chen et al., 2004; Heinisch et al., 2011) we hypothesize that crosstalk between opioid and chemokine receptors via heterologous desensitization can be another reason of decreased analgesic effect of opioids. Heterologous desensitization is observed in cells that express multiple types of GPCRs when the activation of one type of receptor leads to the changes of other types due to activation of several protein kinases (Kelly et al., 1999; Zhang et al., 2004). Moreover, activation of opioid receptors by an agonist induces changes in some chemokine levels 

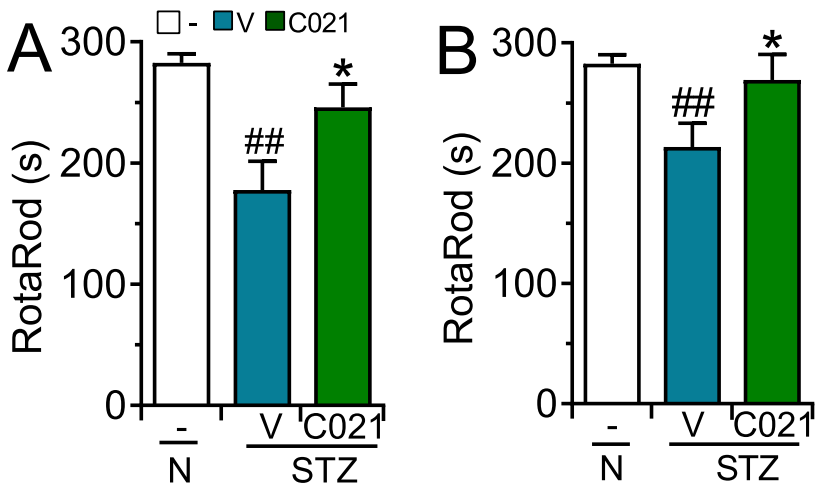

Fig. 7. The intrathecal and intraperitoneal injection of $C_{021}$ beneficially affected motor coordination 7 days after STZ treatment in mice. The effects of a single injection of $\mathrm{V}$ or $\mathrm{C} 021(30 \mu \mathrm{g} /$ $5 \mu \mathrm{l}$ i.t., $\mathbf{A}$ and $20 \mathrm{mg} / \mathrm{kg}$ i.p., B) were measured $1 \mathrm{~h} 15 \mathrm{~min}$ after $\mathrm{V}$ or antagonist administration by the rotarod test. ${ }^{*} p<0.05$ indicates significant differences between the V-treated and C021-treated STZexposed animals. Data are presented as the mean \pm SEM, total number of animals: 48 mice: (A, B) $n=8-12$ mice per group. ${ }^{\# \#} p<0.01$ indicates differences between the naive and the $V$-treated STZ-exposed animals. Abbreviations: N, naive, V, water for injection; C021, C021 dichydrochloride (CCR4 antagonist); STZ, streptozotocin.

and chemokine receptor expression (Wetzel et al., 2000; Mahajan et al., 2002; Happel et al., 2008). Ligands which bind to chemokine receptors can desensitize opioid receptors, and by this mechanism decreases the opioid analgesia. It has been already shown that chemokine ligands e.g. CXCL12 and CCL5 induce the phosphorylation of MOR and influence the perception of pain by cross-desensitizing of this opioid receptor (Szabo et al., 2002). In 2014, Ye et al. described heterologous desensitization between CXCR3-MOR, which results in suppressing morphine analgesic effects (Ye et al., 2014). Others have shown that morphine can increase CCR5 expression and that CCR5-MOR also may crosstalk with each other by dimerization (Miyagi et al., 2000; Yuan et al., 2012 , 2013). Therefore, pharmacological targeting of heterodimers is a useful method to modulate opioid receptor activity (Yuan et al., 2012, 2013; Akgün et al., 2015). Recently, Akgün and coworkers synthesized bivalent ligands (MCC series) that contain 2 pharmacophores (a mu opioid agonist and a CCR5 antagonist), which diminished inflammation-induced pain-related behavior; this synthesis is an interesting therapeutic strategy (Akgün et al., 2015). However, the CCR5 antagonist has no analgesic properties in streptozotocin-induced neuropathy (Rojewska et al., 2018); therefore, we suggest that for diabetes therapy, the creation of bivalent ligands that contain MOR agonist and CCR4 antagonist pharmacophores would be more valuable.

Our results are worth emphasizing because we provide the first evidence that CCR4 antagonists can enhance morphine and buprenorphine analgesia in neuropathic pain, which may be relevant for clinical applications in the future. Equally important are the data showing that CCR4 blockade is also beneficial for wound healing in diabetes (Barros et al., 2019). From a clinical perspective it is worth to point out that in our mice model of diabetes-induced neuropathic pain we did not observed any side effects in C021 (CCR4 antagonist) treated animals and, what is very important, mice have revealed reduced tactile and thermal hypersensitivity. Our behavioral tests also showed that CCR4 antagonist has positive impact on motor coordination of animals. It is known that any drug or substance can induce some side effects. This cannot also be ruled out for CCR4 targeted drugs. Due to the fact that CCR4 is expressed by Th2 and Treg cells, it become potential therapeutic point for treatment of allergic diseases such as asthma and atopic dermatitis, as well as Adult T-cell leukemia/lymphoma (ATL) (Yoshie and Matsushima, 2015). The pharmaceutical company Kyowa Hakko Kirin, developed fully humanized monoclonal antibody targeting CCR4, named Mogamulizumab (Yu et al., 2017). During I and II phase of clinical trials in patients with ATL this antibody was well-tolerated, but in few cases induced skin-related adverse effects, which might be correlated with almost total absence of Treg cells (Ishida et al., 2013). Therefore, in order to determine if and what side effects CCR4oriented therapy can bring under diabetic neuropathy, we definitely need a long studies involving both animal and human ones. Moreover, the gender-related differences need to be study, especially since females often have more serious complications during diabetes (Centers for Disease Control and Prevention, 2018). Overall, these data emphasized CCR4 as a promising target to be exploited as a novel therapeutic approach for the polytherapy of diabetic-based neuropathic pain.

In conclusion, diabetic neuropathy is a serious and common complication of diabetes that is associated with increased risks of mortality and cardiovascular diseases. In light of our current results, we can confidently state that CCR4 signaling plays an important role in a mouse model of diabetic neuropathy. These findings support the hypothesis that the blockade of CCR4 signaling has a positive feedback role in the regulation of morphine and buprenorphine analgesia. Therefore, blocking CCR4 may represent a new strategy for effective polytherapy with opioids, which may provide a rational strategy in patients suffering from diabetic neuropathic pain.

\section{ACKNOWLEDGMENTS}

This work was supported by the National Science Centre, Poland (OPUS 11 2016/21/B/NZ4/00128) and by statutory funds from the Maj Institute of Pharmacology Polish Academy of Sciences, Department of Pain Pharmacology. Joanna Bogacka acknowledges the support of InterDokMed project no. POWR.03.02.00-001013/16. We thank Magdalena Zychowska for technical support in the analysis of CCL2 using the RayBio antibody array.

\section{CONFLICT OF INTEREST STATEMENT}

The authors declare that the research was conducted in the absence of any commercial or financial relationships that could be construed as a potential conflict of interest. 


\section{ETHICAL APPROVAL}

All applicable international, national, and institutional guidelines for the care and use of animals were followed. All procedures involving animals were performed in accordance with the ethical standards of the International Association for the Study of Pain and the National Institutes of Health Guide for the Care and Use of Laboratory and approved by the II Local Ethics Committee branch of the National Ethics Committee for Experiments on Animals based at the Maj Institute of Pharmacology, Polish Academy of Sciences, Krakow, Poland.

\section{REFERENCES}

Abi-Younes S, Si-Tahar M, Luster AD (2001) The CC chemokines MDC and TARC induce platelet activation via CCR4. Thrombosis Res 101(4):279-289. Available at: https://www.sciencedirect. com/science/article/pii/S0049384800004023**via*3Dihub\#BIB14 [Accessed January 17, 2020].

Akgün E, Javed MI, Lunzer MM, Powers MD, Sham YY, Watanabe Y, Portoghese PS (2015) inhibition of inflammatory and neuropathic pain by targeting a $\mathrm{Mu}$ opioid receptor/chemokine receptor5 heteromer (MOR-CCR5). J Med Chem 58:8647-8657 Available at: http://www.ncbi.nlm.nih.gov/pubmed/26451468 [Accessed March 9, 2020].

Alferink J, Lieberam I, Reindl W, Behrens A, Weiss S, Hüser N, Gerauer K, Ross R, Reske-Kunz AB, Ahmad-Nejad P, Wagner H, Förster I (2003) Compartmentalized production of CCL17 in vivo: strong inducibility in peripheral dendritic cells contrasts selective absence from the spleen. J Exp Med 197:585-599 Available at: http://www.ncbi.nlm.nih.gov/pubmed/12615900 [Accessed January 17, 2020].

Anderson JT, Cornelius JG, Jarpe AJ, Winter WE, Peck AB (1993) Insulin-dependent diabetes in the nod mouse model II. $\beta$ cell destruction in autoimmune diabetes is a th2 and not a th1 mediated event. Autoimmunity 15:113-122.

Aye-Mon A, Hori K, Kozakai Yu, Nakagawa T, Hiraga S, Nakamura T, Shiraishi Y, Okuda H, Ozaki N (2018) CCR2 upregulation in DRG neurons plays a crucial role in gastric hyperalgesia associated with diabetic gastropathy. Mol Pain 14:174480. https://doi.org/ 10.1177/1744806917751322. Available at: http://www.ncbi.nlm. nih.gov/pubmed/29359616 [Accessed March 9, 2020].

Azar ST, Tamim H, Beyhum HN, Zouhair Habbal M, Almawi WY (1999) Type I (insulin-dependent) diabetes is a Th1- and Th2mediated autoimmune disease. Clin Diagn Lab Immunol 6:306-310.

Barros JF, Waclawiak I, Pecli C, Borges PA, Georgii JL, RamosJunior ES, Canetti C, Courau T, Klatzmann D, Kunkel SL, Penido C, Canto FB, Benjamim CF (2019) Role of Chemokine Receptor CCR4 and Regulatory T Cells in Wound Healing of Diabetic Mice. J Invest Dermatol 139:1161-1170 Available at: https://www. sciencedirect.com/science/article/abs/pii/S0022202X18328239** via*3Dihub [Accessed March 9, 2020].

Bishnoi M, Bosgraaf CA, Abooj U, Zhong L, Premkumar LS (2011) Streptozotocin-induced early thermal hyperalgesia is independent of glycemic state of rats: role of transient receptor potential vanilloid 1(TRPV1) and Inflammatory Mediators. Mol Pain 7:1744. Available at: https://www.ncbi.nlm.nih.gov/pmc/articles/ PMC3157448/ [Accessed March 9, 2020].

Bogacka J, Popiolek-Barczyk K, Pawlik K, Ciechanowska A, Makuch W, Rojewska E, Dobrogowski J, Przeklasa-Muszynska A, Mika J (2020) CCR4 antagonist (C021) influences the level of nociceptive factors and enhances the analgesic potency of morphine in a rat model of neuropathic pain. Eur $\mathrm{J}$ Pharmacol 880:173166. Available at: https://pubmed.ncbi.nlm.nih.gov/ 32407723/ [Accesed May, 26, 2020].
Bogacka J, Ciapała K, Pawlik K, Kwiatkowski K, Dobrogowski J, Przeklasa-Muszynska A, Mika J CCR4 Antagonist (C021) Administration Diminishes Hypersensitivity and Enhances the Analgesic Potency of Morphine and Buprenorphine in a Mouse Model of Neuropathic Pain. Front Immunol - in press.

Brack A, Rittner HL, Machelska H, Leder K, Mousa SA, Schäfer M, Stein C (2004) Control of inflammatory pain by chemokinemediated recruitment of opioid-containing polymorphonuclear cells. Pain 112:229-238.

Castany S, Carcolé M, Leánez S, Pol O (2016) The antinociceptive effects of a $\delta$-opioid receptor agonist in mice with painful diabetic neuropathy: Involvement of heme oxygenase 1. Neurosci Lett 614:49-54. Available at: https://www.sciencedirect.com/science/ article/pii/S0304394015303505**via*3Dihub [Accessed March 9, 2020]..

Centers for Disease Control and Prevention (2018) Diabetes and Women. Available at: https://www.cdc.gov/diabetes/library/ features/diabetes-and-women. htm| ${ }^{\star \star}$ fbclid = IwAR1 1rOwuMTFgcW-uTh4wZ4j-Egl2frb7DysnGVpiTlyt4fJ5bEa368Lv3KM [Accessed May 28, 2020].

Chen C, Chu SF, Di AQ, Zhang Z, Guan FF, Wang SS, Dong YX, Zhu J, Jian WX, Chen NH (2019) CKLF1 aggravates focal cerebral ischemia injury at early stage partly by modulating microglia/macrophage toward M1 polarization through CCR4. Cell Mol Neurobiol 39:651-669.

Chen C, Li J, Bot G, Szabo I, Rogers TJ, Liu-Chen LY (2004) Heterodimerization and cross-desensitization between the $\mu$ opioid receptor and the chemokine CCR5 receptor. Eur J Pharmacol 483:175-186.

Chen M-L, Cao H, Chu Y-X, Cheng L-Z, Liang L-L, Zhang Y-Q, Zhao Z-Q (2012) Role of P2X7 receptor-mediated IL-18/IL-18R signaling in morphine tolerance: multiple glial-neuronal dialogues in the rat spinal cord. The Journal of Pain 13 (10):945-958. Available at: https:// www.sciencedirect.com/science/article/abs/pii/ S1526590012007055**via*3Dihub [Accessed March 9, 2020].

Chen X, Geller EB, Rogers TJ, Adler MW (2007) Rapid heterologous desensitization of antinociceptive activity between mu or delta opioid receptors and chemokine receptors in rats. Drug Alcohol Depend 88:36-41.

Cheng X, Wu H, Jin ZJ, Ma D, Yuen S, Jing XQ, Shi MM, Shen BY, Peng CH, Zhao R, Qiu WH (2017) Up-regulation of chemokine receptor CCR4 is associated with Human Hepatocellular Carcinoma malignant behavior. Sci Rep 7:1-14.

Chomczynski P, Sacchi N (2006) The single-step method of RNA isolation by acid guanidinium thiocyanate-phenol-chloroform extraction: Twenty-something years on. Nat Protoc 1:581-585.

Chou S-Y, Ajoy R, Changou CA, Hsieh Y-T, Wang Y-K, Hoffer B (2016) CCL5/RANTES contributes to hypothalamic insulin signaling for systemic insulin responsiveness through CCR5. Sci Rep 6(1). Available at: http://www.nature.com/articles/srep37659 [Accessed March 9, 2020].

Dai Y, Wu Z, Wang F, Zhang Z, Yu M (2014) Identification of Chemokines and Growth Factors in Proliferative Diabetic Retinopathy Vitreous. BioMed Res Int 2014:1-9. Available at: http://www.ncbi.nlm.nih.gov/pubmed/25401103 [Accessed March $9,2020]$.

Demirseren DD, Emre S, Akoglu G, Arpacı D, Arman A, Metin A, Cakır B (2014) Relationship between skin diseases and extracutaneous complications of diabetes mellitus: clinical analysis of 750 patients. Am J Clin Dermatol 15:65-70.

Deshmane SL, Kremlev S, Amini S, Sawaya BE (2009) Monocyte chemoattractant protein-1 (MCP-1): an overview. J Interferon Cytokine Res 29(6):313-326. Available at: http://www.ncbi.nlm. nih.gov/pubmed/25401103 [Accessed March 9, 2020].

Dogrul A, Gul H, Yesilyurt O, Ulas UH, Yildiz O (2011) Systemic and spinal administration of etanercept, a tumor necrosis factor alpha inhibitor, blocks tactile allodynia in diabetic mice. Acta Diabetol 48 (2):135-142. Available at: http://link.springer.com/10.1007/ s00592-010-0237-x [Accessed March 9, 2020]. 
Fairbanks CA (2003) Spinal delivery of analgesics in experimental models of pain and analgesia. Adv Drug Delivery Rev 55 (8):1007-1041. Available at: https:// www.sciencedirect.com/science/article/pii/

S0169409X03001017**via*3Dihub [Accessed January 17, 2020].

Feldman EL, Nave K-A, Jensen TS, Bennett DLH (2017) New horizons in diabetic neuropathy: mechanisms, bioenergetics, and pain. Neuron 93(6):1296-1313. Available at: https:// www.sciencedirect.com/science/article/pii/ S0896627317300892**via*3Dihub [Accessed March 9, 2020].

Ferrini F, Trang T, Mattioli T-A, Laffray S, Del'Guidice T, Lorenzo L-E, Castonguay A, Doyon N, Zhang W, Godin AG, Mohr D, Beggs S, Vandal K, Beaulieu J-M, Cahill CM, Salter MW, De Koninck Y (2013) Morphine hyperalgesia gated through microglia-mediated disruption of neuronal $\mathrm{Cl}-$ homeostasis. Nat Neurosci 16 (2):183-192. Available at: http://www.nature.com/articles/ nn.3295 [Accessed February 19, 2020].

Flynn G, Maru S, Loughlin J, Romero IA, Male D (2003) Regulation of chemokine receptor expression in human microglia and astrocytes. J Neuroimmunol 136(1-2):84-93. Available at: https://www.sciencedirect.com/science/article/pii/ S0165572803000092**via*3Dihub [Accessed January 16, 2020].

Fülle L, Offermann N, Hansen JN, Breithausen B, Erazo AB, Schanz O, Radau L, Gondorf F, Knöpper K, Alferink J, Abdullah Z, Neumann $H$, Weighardt $H$, Henneberger C, Halle A, Förster I (2018) CCL17 exerts a neuroimmune modulatory function and is expressed in hippocampal neurons. Glia 66(10):2246-2261. Available at: http://doi.wiley.com/10.1002/glia.23507 [Accessed January 17, 2020].

Garcia JJ, Cidoncha A, Bote ME, Hinchado MD, Ortega E (2014) Altered profile of chemokines in fibromyalgia patients. Ann Clin Biochem 51(5):576-581. Available at: http://acb.sagepub.com/ lookup/doi/10.1177/0004563213506413 [Accessed January 17, 2020].

Graves DT, Jiang Y, Valente AJ (1999) Regulated expression of MCP-1 by osteoblastic cells in vitro and in vivo. Histol Histopathol 14:1347-1354.

Happel C, Steele AD, Finley MJ, Kutzler MA, Rogers TJ (2008) DAMGO-induced expression of chemokines and chemokine receptors: the role of TGF-1. J Leukoc Biol 83:956-963 Available at: http://doi.wiley.com/10.1189/jlb.1007685 [Accessed April 23, 2020].

Heinisch S, Palma J, Kirby LG (2011) Interactions between chemokine and mu-opioid receptors: anatomical findings and electrophysiological studies in the rat periaqueductal grey. Brain Behav Immun 25:360-372.

Hu Z, Lancaster JN, Sasiponganan C, Ehrlich LIR (2015) CCR4 promotes medullary entry and thymocyte-Dendritic cell interactions required for central tolerance. J Exp Med 212:1947-1965.

Hylden JLK, Wilcox GL (1980) Intrathecal morphine in mice: a new technique. Eur J Pharmacol 67(2-3):313-316. Available at: https://www.sciencedirect.com/science/article/pii/ 0014299980905154**via*3Dihub [Accessed June 5, 2018].

Imai T, Baba M, Nishimura M, Kakizaki M, Takagi S, Yoshie O (1997) The T cell-directed CC chemokine TARC is a highly specific Biological ligand for CC chemokine receptor 4. J. Biol. Chem. 272 (23):15036-15042. Available at: http://www.ncbi.nlm.nih.gov/ pubmed/9169480 [Accessed January 17, 2020].

Ishida $\mathrm{T}$, Ito $\mathrm{A}$, Sato $\mathrm{F}$, Kusumoto $\mathrm{S}$, lida $\mathrm{S}$, Inagaki H, Morita A, Akinaga S, Ueda R (2013) Stevens-Johnson Syndrome associated with mogamulizumab treatment of adult T-cell leukemia / lymphoma. Cancer Sci 104(5):647-650. Available at: http://doi.wiley.com/10.1111/cas.12116 [Accessed April 22, 2020].

Jacobs JFM, Idema AJ, Bol KF, Grotenhuis JA, de Vries IJM, Wesseling P, Adema GJ (2010) Prognostic significance and mechanism of Treg infiltration in human brain tumors. J Neuroimmunol 225:195-199.

Jafarzadeh A, Arabi Z, Ahangar-Parvin R, Mohammadi-Kordkhayli M, Nemati M (2017) Ginger extract modulates the expression of chemokines CCL20 and CCL22 and their receptors (CCR6 and
CCR4) in the central nervous system of mice with experimental autoimmune encephalomyelitis. Drug Res (Stuttg) 67 (11):632-639. Available at: http://www.thieme-connect.de/DOI/ DOI**10.1055/s-0043-113455 [Accessed January 17, 2020].

Ji W, Huang H, Chao Ji, Lu W, Guo J (2014) Protective effect of Agaricus brasiliensis on STZ-induced diabetic neuropathic pain in rats. Evidence-Based Complementary Alternative Med 2014:1-6. Available at: http://www.ncbi.nlm.nih.gov/pubmed/24527050 [Accessed March 9, 2020].

Kamei J, Ohhashi Y, Aoki T, Kasuya Y (1991) Streptozotocin-induced diabetes in mice reduces the nociceptive threshold, as recognized after application of noxious mechanical stimuli but not of thermal stimuli. Pharmacol Biochem Behav 39(2):541-544. Available at: https://www.sciencedirect.com/science/article/pii/ $009130579190224 \mathrm{P}^{* *}$ via*3Dihub [Accessed March 9, 2020].

Kelly MJ, Lagrange AH, Wagner EJ, Rønnekleiv OK (1999) Rapid effects of estrogen to modulate $G$ protein-coupled receptors via activation of protein kinase $A$ and protein kinase $C$ pathways. In: Steroids, pp 64-75. Elsevier.

Kiguchi N, Ding H, Peters CM, Kock ND, Kishioka S, Cline JM, Wagner JD, Ko M-C (2017) Altered expression of glial markers, chemokines, and opioid receptors in the spinal cord of type 2 diabetic monkeys. Biochim Biophys Acta 1863(1):274-283. Available at: http://www.ncbi.nlm.nih.gov/pubmed/27751964 [Accessed January 17, 2020].

Klein A, Sagi-Assif O, Meshel T, Telerman A, Izraely S, BenMenachem S, Bayry J, Marzese DM, Ohe S, Hoon DSB, Erez N, Witz IP (2017) CCR4 is a determinant of melanoma brain metastasis. Oncotarget 8(19):31079-31091. Available at: http:// www.ncbi.nlm.nih.gov/pubmed/28415693 [Accessed March 9, 2020].

Kou Z-Z, Wan F-P, Bai Y, Li C-Y, Hu J-C, Zhang G-T, Zhang T, Chen T, Wang Y-Y, Li H, Li Y-Q (2016) Decreased Endomorphin-2 and $\mu$-Opioid Receptor in the Spinal Cord Are Associated with Painful Diabetic Neuropathy. Front Mol Neurosci 9:80 Available at: http:// journal.frontiersin.org/Article/10.3389/fnmol.2016.00080/abstract [Accessed March 9, 2020].

Kwiatkowski K, Mika J (2018) The importance of chemokines in neuropathic pain development and opioid analgesic potency. Pharmacol Reports 70(4):821-830. Available at: http://www.ncbi. nlm.nih.gov/pubmed/30122168 [Accessed April 23, 2020].

Kwiatkowski K, Piotrowska A, Rojewska E, Makuch W, Jurga A, Slusarczyk J, Trojan E, Basta-Kaim A, Mika J (2016) Beneficial properties of maraviroc on neuropathic pain development and opioid effectiveness in rats. Progress Neuro-Psychopharmacol Biol Psychiatry 64:68-78. Available at: https:// www.sciencedirect.com/science/article/pii/ S0278584615300130**via*3Dihub [Accessed January 16, 2020].

Kwiatkowski K, Piotrowska A, Rojewska E, Makuch W, Mika J (2017) The RS504393 influences the level of nociceptive factors and enhances opioid analgesic potency in neuropathic rats. J Neuroimmune Pharmacol 12(3):402-419. Available at: http:// www.ncbi.nlm.nih.gov/pubmed/28337574 [Accessed May 29, 2018].

Kwiatkowski K, Popiolek-Barczyk K, Piotrowska A, Rojewska E, Ciapała K, Makuch W, Mika J (2019) Chemokines CCL2 and CCL7, but not CCL12, play a significant role in the development of pain-related behavior and opioid-induced analgesia. Cytokine 119:202-213. Available at: https:// www.sciencedirect.com/science/article/pii/

S1043466619300845**via*3Dihub [Accessed January 17, 2020].

Lenzen S (2008) The mechanisms of alloxan- and streptozotocininduced diabetes. Diabetologia 51(2):216-226. Available at: http://link.springer.com/10.1007/s00125-007-0886-7 [Accessed March 9, 2020].

Li JY, Ou ZL, Yu SJ, Gu XL, Yang C, Chen AX, Di GH, Shen ZZ, Shao ZM (2012) The chemokine receptor CCR4 promotes tumor growth and lung metastasis in breast cancer. Breast Cancer Res Treat 131:837-848.

Mahajan SD, Schwartz SA, Shanahan TC, Chawda RP, Nair MPN (2002) Morphine regulates gene expression of $\alpha$ - and $\beta$ - 
chemokines and their receptors on astroglial cells via the opioid $\mu$ receptor. J Immunol 169:3589-3599.

Maolake A, Izumi K, Shigehara K, Natsagdorj A, Iwamoto H, Kadomoto S, Takezawa Y, Machioka K, Narimoto K, Namiki M, Lin WJ, Wufuer G, Mizokami A (2017) Tumor-associated macrophages promote prostate cancer migration through activation of the CCL22-CCR4 axis. Oncotarget 8:9739-9751.

Matsuo K, Nagakubo D, Komori Y, Fujisato S, Takeda N, Kitamatsu M, Nishiwaki K, Quan Y-S, Kamiyama F, Oiso N, Kawada A, Yoshie O, Nakayama T (2018) CCR4 is critically involved in skin allergic inflammation of BALB/c Mice. J Investigative Dermatol 138(8):1764-1773. Available at: https:// www.sciencedirect.com/science/article/pii/

S0022202X18302008**via*3Dihub [Accessed January 17, 2020].

Matsushita K, Tozaki-Saitoh H, Kojima C, Masuda T, Tsuda M, Inoue K, Hoka S (2014) Chemokine (C-C motif) receptor 5 is an important pathological regulator in the development and maintenance of neuropathic pain. Anesthesiology 120 (6):1491-1503. Available at: http://anesthesiology.pubs.asahq. org/Article. aspx ${ }^{* *}$ doi $=10.1097 /$ ALN. 0000000000000190 [Accessed January 16, 2020].

McMillin M, Frampton G, Thompson M, Galindo C, Standeford H, Whittington E, Alpini G, DeMorrow S (2014) Neuronal CCL2 is upregulated during hepatic encephalopathy and contributes to microglia activation and neurological decline. $J$ Neuroinflammation 11(1):121. Available at: http://www.ncbi.nlm. nih.gov/pubmed/25012628 [Accessed January 16, 2020].

Meucci O, Fatatis A, Simen AA, Bushell TJ, Gray PW, Miller RJ (1998) Chemokines regulate hippocampal neuronal signaling and gp120 neurotoxicity. Proc Natl Acad Sci 95(24):14500-14505. Available at: http://www.ncbi.nlm.nih.gov/pubmed/9826729 [Accessed January 16, 2020].

Mika J (2008) Modulation of microglia can attenuate neuropathic pain symptoms and enhance morphine effectiveness. Pharmacol Rep 60:297-307 Available at: http://www.ncbi.nlm.nih.gov/pubmed/ 18622054 [Accessed May 30, 2018].

Mika J, Zychowska M, Popiolek-Barczyk K, Rojewska E, Przewlocka B (2013) Importance of glial activation in neuropathic pain. Eur J Pharmacol 716(1-3):106-119. Available at: http://www.ncbi.nlm. nih.gov/pubmed/23500198 [Accessed May 29, 2018].

Miller RE, Tran PB, Das R, Ghoreishi-Haack N, Ren D, Miller RJ, Malfait A-M (2012) CCR2 chemokine receptor signaling mediates pain in experimental osteoarthritis. Proc Natl Acad Sci 109 (50):20602-20607. Available at: http://www.ncbi.nlm.nih.gov/ pubmed/23185004 [Accessed March 9, 2020].

Miyagi T, Chuang LF, Doi RH, Carlos MP, Torres JV, Chuang RY (2000) Morphine induces gene expression of CCR5 in human CEM x174 lymphocytes. J Biol Chem 275:31305-31310.

Mizisin AP (2014) Mechanisms of diabetic neuropathy: Schwann cells. Handb Clin Neurol 126:401-428 Available at: https:// www.sciencedirect.com/science/article/pii/

B9780444534804000291**via*3Dihub [Accessed March 9, 2020].

Morgado C, Pereira-Terra P, Cruz CD, Tavares I (2011) Minocycline completely reverses mechanical hyperalgesia in diabetic rats through microglia-induced changes in the expression of the potassium chloride co-transporter 2 (KCC2) at the spinal cord. Diabetes, Obes Metab 13:150-159 Available at: http://doi. wiley.com/10.1111/j.1463-1326.2010.01333.x [Accessed March $9,2020]$.

Moriguchi K, Miyamoto K, Tanaka N, Ueno R, Nakayama T, Yoshie O, Kusunoki S (2016) C-C chemokine receptor type 4 antagonist Compound 22 ameliorates experimental autoimmune encephalomyelitis. J of Neuroimmunol 291:54-58. Available at: https://www.sciencedirect.com/science/article/pii/ S0165572815301041**via*3Dihub [Accessed January 17, 2020].

Mueller MJ, Minor SD, Sahrmann SA, Schaaf JA, Strube MJ (1994) Differences in the Gait Characteristics of Patients With Diabetes and Peripheral Neuropathy Compared With Age-Matched Controls. Phys Ther 74:299-308 Available at: http://www.ncbi. nlm.nih.gov/pubmed/8140143 [Accessed March 9, 2020].
Murakami T, Iwanaga T, Ogawa Y, Fujita Y, Sato E, Yoshitomi H, Sunada Y, Nakamura A (2013) Development of sensory neuropathy in streptozotocin-induced diabetic mice. Brain Behav 3(1):35-41. Available at: http://www.ncbi.nlm.nih.gov/pubmed/ 23407314 [Accessed March 9, 2020].

Neumann S, Doubell TP, Leslie T, Woolf CJ (1996) Inflammatory pain hypersensitivity mediated by phenotypic switch in myelinated primary sensory neurons. Nature 384(6607):360-364. Available at: http://www.nature.com/articles/384360a0 [Accessed March 9, 2020].

Nomiyama H, Imai T, Kusuda J, Miura R, Callen DF, Yoshie O (1997) Assignment of the human CC chemokine gene TARC (SCYA17) to chromosome 16q13. Genomics 40(1):211-213. Available at: https://www.sciencedirect.com/science/article/pii/ S0888754396945528**via*3Dihub [Accessed January 17, 2020].

Ohsawa M, Aasato M, Hayashi S-S, Kamei J (2011) RhoA/Rho kinase pathway contributes to the pathogenesis of thermal hyperalgesia in diabetic mice. Pain 152(1):114-122. Available at: http://www.ncbi.nlm.nih.gov/pubmed/20980102 [Accessed March 9, 2020].

Pabreja K, Dua K, Sharma S, Padi SSV, Kulkarni SK (2011) Minocycline attenuates the development of diabetic neuropathic pain: Possible anti-inflammatory and anti-oxidant mechanisms. Eur J Pharmacol 661(1-3):15-21. Available at: http://www.ncbi. nlm.nih.gov/pubmed/21536024 [Accessed May 29, 2018].

Panee J (2012) Monocyte Chemoattractant Protein 1 (MCP-1) in obesity and diabetes. Cytokine 60(1):1-12. Available at: http:// www.ncbi.nlm.nih.gov/pubmed/22766373 [Accessed March 9, 2020].

Pawlik K, Piotrowska A, Kwiatkowski K, Ciapała K, Popiolek-Barczyk K, Makuch W, Mika J (2020) The blockade of CC chemokine receptor type 1 influences the level of nociceptive factors and enhances opioid analgesic potency in a rat model of neuropathic pain. Immunology:imm.13172 Available at: https://onlinelibrary. wiley.com/doi/abs/10.1111/imm.13172 [Accessed March 9, 2020].

Pease JE, Horuk R (2014) Recent progress in the development of antagonists to the chemokine receptors CCR3 and CCR4. Expert Opin Drug Discovery 9(5):467-483. Available at: http:// www.tandfonline.com/doi/full/10.1517/17460441.2014.897324 [Accessed January 16, 2020].

Pfützner J, Hellhammer J, Musholt P, Pfützner AH, Böhnke J, Hero T, Amann-Zalan I, Ganz M, Forst T, Pfützner A (2011) Evaluation of dexterity in insulin-treated patients with type 1 and type 2 diabetes mellitus. J Diabetes Sci Technol 5(1):158-165. Available at: http:// www.ncbi.nlm.nih.gov/pubmed/21303639 [Accessed March 9, 2020].

Pilat D, Piotrowska A, Rojewska E, Jurga A, Ślusarczyk J, Makuch W, Basta-Kaim A, Przewlocka B, Mika J (2016) Blockade of IL-18 signaling diminished neuropathic pain and enhanced the efficacy of morphine and buprenorphine. Mol Cellular Neurosci 71:114-124. Available at: https:// www.sciencedirect.com/science/article/pii/

S1044743115300531**via*3Dihub [Accessed January 20, 2020].

Pilat D, Rojewska E, Jurga AM, Piotrowska A, Makuch W, Przewlocka B, Mika J (2015) IL-1 receptor antagonist improves morphine and buprenorphine efficacy in a rat neuropathic pain model. Eur J Pharmacol 764:240-248. Available at: https:// www.sciencedirect.com/science/article/pii/

S001429991530056X**via*3Dihub [Accessed January 20, 2020].

Piotrowska A, Kwiatkowski K, Rojewska E, Makuch W, Mika J (2016a) Maraviroc reduces neuropathic pain through polarization of microglia and astroglia - Evidence from in vivo and in vitro studies. Neuropharmacology 108:207-219. Available at: http:// www.ncbi.nlm.nih.gov/pubmed/27117708 [Accessed May 18, 2018].

Piotrowska A, Kwiatkowski K, Rojewska E, Slusarczyk J, Makuch W, Basta-Kaim A, Przewlocka B, Mika J (2016b) Direct and indirect pharmacological modulation of CCL2/CCR2 pathway results in attenuation of neuropathic pain - In vivo and in vitro evidence. $J$ 
Neuroimmunol 297:9-19. Available at: https:/l www.sciencedirect.com/science/article/pii/

S0165572816300959**via*3Dihub [Accessed January 16, 2020].

Pop-Busui R, Ang L, Holmes C, Gallagher K, Feldman EL (2016) Inflammation as a therapeutic target for diabetic neuropathies. Curr Diab Rep 16(3). Available at: http://www.ncbi.nlm.nih.gov/ pubmed/26897744 [Accessed March 9, 2020].

Przeklasa-Muszynska A, Dobrogowski J (2011) Transdermal buprenorphine for the treatment of moderate to severe chronic pain: results from a large multicenter, non-interventional postmarketing study in Poland. Curr Med Res Opin 27(6):1109-1117. Available at: http://www.ncbi.nlm.nih.gov/pubmed/21456888 [Accessed March 9, 2020].

Rojas DR, Kuner R, Agarwal N (2018) Metabolomic signature of type 1 diabetes-induced sensory loss and nerve damage in diabetic neuropathy. Available at: http://arxiv.org/abs/1803.06740 [Accessed March 9, 2020].

Rojewska E, Makuch W, Przewlocka B, Mika J (2014) Minocycline prevents dynorphin-induced neurotoxicity during neuropathic pain in rats. Neuropharmacology 86:301-310.

Rojewska E, Zychowska M, Piotrowska A, Kreiner G, Nalepa I, Mika J (2018) Involvement of Macrophage Inflammatory Protein-1 Family Members in the Development of Diabetic Neuropathy and Their Contribution to Effectiveness of Morphine. Front Immunol 9:494 Available at: http://www.ncbi.nlm.nih.gov/pubmed/29593735 [Accessed May 29, 2018].

Ruland C, Renken H, Kuzmanov I, Fattahi Mehr A, Schwarte K, Cerina M, Herrmann A, Otte D-M, Zimmer A, Schwab N, Meuth SG, Arolt V, Klotz L, Förster I, Scheu S, Alferink J (2017) Chemokine CCL17 is expressed by dendritic cells in the CNS during experimental autoimmune encephalomyelitis and promotes pathogenesis of disease. Brain, Behav Immunity 66:382-393. Available at: https:// www.sciencedirect.com/science/article/pii/

S088915911730199X**via*3Dihub\#b0030 [Accessed January 17, 2020].

Safieh-Garabedian B, Nomikos M, Saadé N (2019) Targeting inflammatory components in neuropathic pain: $t /$ he analgesic effect of thymulin related peptide. Neurosci Lett 702:61-65. Available at: https://www.sciencedirect.com/science/article/abs/ pii/S0304394018308279**via*3Dihub [Accessed March 9, 2020].

Sallusto F, Palermo B, Lenig D, Miettinen M, Matikainen S, Julkunen I, Forster R, Burgstahler R, Lipp M, Lanzavecchia A (1999) Distinct patterns and kinetics of chemokine production regulate dendritic cell function. Eur J Immunol 29:1617-1625 Available at: http://doi.wiley.com/10.1002/*28SICl*291521-

$4141^{*} 28199905^{\star} 2929^{*} 3 A_{0} 5^{\star} 3 \mathrm{C} 1617^{*} 3 A^{*} 3$ AAID-

IMMU1617*3E3.0.CO*3B2-3 [Accessed January 17, 2020].

Scheu S, Ali S, Ruland C, Arolt V, Alferink J (2017) The C-C Chemokines CCL17 and CCL22 and Their Receptor CCR4 in CNS Autoimmunity. Int J Mol Sci 18 Available at: http://www.ncbi. nlm.nih.gov/pubmed/29099057 [Accessed January 16, 2020].

Sorensen TL, Ransohoff RM, Strieter RM, Sellebjerg F (2004) Chemokine CCL2 and chemokine receptor CCR2 in early active multiple sclerosis. Eur J Neurol 11(7):445-449. Available at: http://doi.wiley.com/10.1111/j.1468-1331.2004.00796.x [Accessed February 5, 2020].

Starnowska J, Costante R, Guillemyn K, Popiolek-Barczyk K, Chung NN, Lemieux C, Keresztes A, Van Duppen J, Mollica A, Streicher J, Vanden Broeck J, Schiller PW, Tourwé D, Mika J, Ballet S, Przewlocka B (2017) Analgesic properties of opioid/NK1 multitarget ligands with distinct in vitro profiles in naive and chronic constriction injury mice. ACS Chem. Neurosci. 8 (10):2315-2324. Available at: http://www.ncbi.nlm.nih.gov/ pubmed/28699350 [Accessed May 30, 2018].

Stolberg VR, Chiu B-C, Schmidt BM, Kunkel SL, Sandor M, Chensue SW (2011) CC chemokine receptor 4 contributes to innate NK and chronic stage $\mathrm{T}$ helper cell recall responses during mycobacterium bovis infection. Am J Pathol 178(1):233-244. Available at: http://www.ncbi.nlm.nih.gov/pubmed/21224060 [Accessed January 17, 2020].
Szabo I, Chen X-H, Xin L, Adler MW, Howard OMZ, Oppenheim JJ, Rogers TJ (2002) Heterologous desensitization of opioid receptors by chemokines inhibits chemotaxis and enhances the perception of pain. Proc Nat Acad Sci 99(16):10276-10281 Available at: http://www.ncbi.nlm.nih.gov/pubmed/12130663 [Accessed January 16, 2020].

Von Herrath MG, Oldstone MBA (1997) Interferon- $\gamma$ is essential for destruction of $\beta$ cells and development of insulin-dependent diabetes mellitus. J Exp Med 185:531-539.

Wetzel MA, Steele AD, Eisenstein TK, Adler MW, Henderson EE, Rogers TJ (2000) $\mu$-Opioid induction of monocyte chemoattractant protein-1, RANTES, and IFN- $\gamma$-inducible protein-10 expression in human peripheral blood mononuclear cells. J Immunol 165:6519-6524.

WHO (2017) WHO | Global report on diabetes. WHO Available at: https://www.who.int/diabetes/global-report/en/ [Accessed March 9, 2020].

Yamashita U, Kuroda E (2002) Regulation of macrophage-derived chemokine (MDC, CCL22) production. Crit Rev Immunol 22:105114 Available at: http://www.ncbi.nlm.nih.gov/pubmed/12433129 [Accessed January 17, 2020].

Ye D, Bu H, Guo G, Shu B, Wang W, Guan X, Yang H, Tian X, Xiang H, Gao F (2014) Activation of CXCL10/CXCR3 signaling attenuates morphine analgesia: Involvement of Gi protein. J Mol Neurosci 53:571-579.

Yoshie O, Matsushima K (2015) CCR4 and its ligands: from bench to bedside. Int Immunol 27(1):11-20. Available at: https://academic. oup.com/intimm/article-lookup/doi/10.1093/intimm/dxu079 [Accessed January 17, 2020].

Yu X, Marshall MJE, Cragg MS, Crispin M (2017) Improving antibodybased cancer therapeutics through glycan engineering. BioDrugs 31(3):151-166. Available at: http://www.ncbi.nlm.nih.gov/ pubmed/28466278 [Accessed April 22, 2020].

Yuan Y, Arnatt CK, El-Hage N, Dever SM, Jacob JC, Selley DE, Hauser KF, Zhang Y (2013) A Bivalent Ligand Targeting the Putative Mu Opioid Receptor and Chemokine Receptor CCR5 Heterodimers: Binding Affinity versus Functional Activities. Medchemcomm 4:847-851 Available at: http://www.ncbi.nlm. nih.gov/pubmed/23682308 [Accessed February 19, 2020].

Yuan Y, Arnatt CK, Li G, Haney KM, Ding D, Jacob JC, Selley DE, Zhang Y (2012) Design and synthesis of a bivalent ligand to explore the putative heterodimerization of the mu opioid receptor and the chemokine receptor CCR5. Org Biomol Chem 10 (13):2633. Available at: http://www.ncbi.nlm.nih.gov/pubmed/ 22354464 [Accessed February 19, 2020].

Zanjani TM, Sabetkasaei M, Mosaffa N, Manaheji H, Labibi F, Farokhi B (2006) Suppression of interleukin- 6 by minocycline in a rat model of neuropathic pain. Eur J Pharmacol 538(1-3):66-72. Available at: https://www.sciencedirect.com/science/article/abs/ pii/S0014299906003578**via*3Dihub [Accessed March 9, 2020].

Zhang N, Hodge D, Rogers TJ, Oppenheim JJ (2003) Ca2+independent protein kinase Cs mediate heterologous desensitization of leukocyte chemokine receptors by opioid receptors. J Biol Chem 278:12729-12736.

Zhang N, Rogers TJ, Caterina M, Oppenheim JJ (2004) Proinflammatory chemokines, such as $\mathrm{C}-\mathrm{C}$ chemokine ligand 3 , desensitize $\mu$-opioid receptors on dorsal root ganglia neurons. $J$ Immunol 173:594-599.

Zhang T, Somasundaram R, Berencsi K, Caputo L, Gimotty P, Rani P, Guerry DuPont, Swoboda R, Herlyn D (2006) Migration of cytotoxic $T$ lymphocytes toward melanoma cells in threedimensional organotypic culture is dependent on CCL2 and CCR4. Eur J Immunol 36(2):457-467. Available at: http://doi. wiley.com/10.1002/eji.200526208 [Accessed April 23, 2020].

Zhang Y, Wu Y, Qi H, Xiao J, Gong H, Zhang Y, Xu E, Li S, Ma D, Wang Y, Li W, Shen H (2017) A new antagonist for CCR4 attenuates allergic lung inflammation in a mouse model of asthma. Sci Rep 7(1). Available at: http://www.nature.com/ articles/s41598-017-11868-9 [Accessed January 17, 2020].

Zhao C-M, Guo R-X, Hu F, Chen P-x, Cui Yu, Feng J-Q, Meng J-L, Mo L-Q, Liao X-X (2012) Spinal MCP-1 contributes to the 
development of morphine antinociceptive tolerance in rats. Am J Med Sci 344(6):473-479. Available at: https:// www.sciencedirect.com/science/article/abs/pii/ S0002962915307886**via*3Dihub [Accessed January 20, 2020].

Zimmermann M (1983) Ethical guidelines for investigations of experimental pain in conscious animals. Pain 16:109-110.

Zou W, Curiel T, Zou L, Coukos G, Kryczek I (2005) Specific recruitment of regulatory $T$ cells in ovarian carcinoma fosters immune privilege and predicts reduced survival. Cancer Res 65.

Zurek JR, Nadeson R, Goodchild CS (2001) Spinal and supraspinal components of opioid antinociception in streptozotocin induced diabetic neuropathy in rats. Pain 90(1):57-63. Available at: http:// www.ncbi.nlm.nih.gov/pubmed/11166970 [Accessed March 9, 2020].

Zychowska M, Rojewska E, Kreiner G, Nalepa I, Przewlocka B, Mika $J$ (2013a) Minocycline influences the anti-inflammatory interleukins and enhances the effectiveness of morphine under mice diabetic neuropathy. J Neuroimmunol 262(1-2):35-45. Available at: https://www.sciencedirect.com/science/article/pii/ S0165572813001641**via*3Dihub [Accessed March 9, 2020].
Zychowska M, Rojewska E, Pilat D, Mika J (2015) The role of some chemokines from the CXC subfamily in a mouse model of diabetic neuropathy. J Diabetes Res 2015:1-13. Available at: http://www. ncbi.nlm.nih.gov/pubmed/25789329 [Accessed March 9, 2020].

Zychowska M, Rojewska E, Piotrowska A, Kreiner G, Mika J (2016) Microglial inhibition influences XCL1/XCR1 expression and causes analgesic effects in a mouse model of diabetic neuropathy. Anesthesiology 125(3):573-589. Available at: http:// insights.ovid.com/crossref*an $=00000542-201609000-00027$ [Accessed March 9, 2020].

Zychowska M, Rojewska E, Piotrowska A, Kreiner G, Nalepa I, Mika J (2017) Spinal CCL1/CCR8 signaling interplay as a potential therapeutic target - Evidence from a mouse diabetic neuropathy model. Int Immunopharmacol 52:261-271. Available at: http:// www.ncbi.nlm.nih.gov/pubmed/28961489 [Accessed May 29, 2018].

Zychowska M, Rojewska E, Przewlocka B, Mika J (2013b) Mechanisms and pharmacology of diabetic neuropathy experimental and clinical studies. Pharmacol Reports 65 (6):1601-1610. Available at: http://www.ncbi.nlm.nih.gov/ pubmed/24553008 [Accessed May 29, 2018].

(Received 25 March 2020, Accepted 17 June 2020)

(Available online 24 June 2020) 